\title{
The Globalization of Angel Investments: Evidence across Countries
}

\section{Citation}

Lerner, Josh, Antoinette Schoar, Stanislav Sokolinski, and Karen Wilson. "The Globalization of Angel Investments: Evidence across Countries." Harvard Business School Working Paper, No. 16-072, December 2015.

\section{Permanent link}

http://nrs.harvard.edu/urn-3:HUL.InstRepos:24009685

\section{Terms of Use}

This article was downloaded from Harvard University's DASH repository, and is made available under the terms and conditions applicable to Open Access Policy Articles, as set forth at http:// nrs.harvard.edu/urn-3:HUL.InstRepos:dash.current.terms-of-use\#OAP

\section{Share Your Story}

The Harvard community has made this article openly available.

Please share how this access benefits you. Submit a story.

Accessibility 


\section{The Globalization of Angel Investments: Evidence across Countries}

Josh Lerner

Stanislav Sokolinski
Antoinette Schoar

Karen Wilson

Working Paper 16-072 


\section{The Globalization of Angel Investments: Evidence across Countries}

\author{
Josh Lerner \\ Harvard University \\ Stanislav Sokolinski \\ Harvard University
}

\author{
Antoinette Schoar \\ Massachusetts Institute of Technology \\ Karen Wilson \\ Bruegel
}

Working Paper 16-072 


\section{The Globalization of Angel Investments:}

\section{Evidence across Countries}

Josh Lerner, Antoinette Schoar, Stanislav Sokolinski, and Karen Wilson

Harvard University, MIT, Harvard University, and Bruegel ${ }^{1}$

November 16, 2015

This paper examines investments made by 13 angel groups across 21 countries. We compare applicants just above and below the funding cut-off and find that these angel investors have a positive impact on the growth, performance, and survival of firms as well as their follow-on fundraising. The positive impact of angel financing is independent of the level of venture activity and entrepreneur friendliness in the country. But we find that the development stage and maturity of start ups that apply for angel funding (and those that are ultimately funded) is inversely correlated with the entrepreneurship friendliness of the country, which may reflect self-censoring by very early stage firms who do not expect to receive funding in these environments.

${ }^{1}$ Lerner and Schoar are also affiliates of the National Bureau of Economic Research. Wilson is also affiliated with the Organisation for Economic Cooperation and Development. We thank numerous angel groups for their willingness to share data and their patience in answering our many queries. Excellent research assistance was provided by Secil Altintas, Jamie Beaton, Elaine Dai, Kenneth Fu, Ida Hempel, Zaahid Khan, Michelle Lin, and Ahmed Zaeem, and the research team at Baker Library led by Sarah Eriksen. Seminar participants at the Angel Capital Association, Boston University, London Business School, the National Bureau of Economic Research, and the University of Texas, and especially Shai Bernstein, Thomas Hellmann, Arthur Korteweg, and Ramana Nanda provided helpful comments. We thank the Harvard Business School's Division of Research and the Ewing Marion Kauffman Foundation for financial support. All errors and omissions are our own. 


\section{Introduction}

The last decade has seen a rapid expansion and deepening of the types of vehicles that fund start-up firms in the U.S. and worldwide. In particular, we have seen a growing role of angel groups and other more "individualistic" funding options for start-ups, such as super angels or crowd sourcing platforms. This trend has not only been prevalent in the U.S., but also in many other nations (OECD, 2011; Wilson, 2105; OECD 2016). One could argue that the funding of new ventures by wealthy individuals is one of the oldest forms of outside investment that exists, especially where capital markets and financial institutions are less developed. In this paper, however, we focus on the organized angel market as a growing form of start-up investing that is less formal than the VC market but more professional than getting funding from friends and family.

The precise measurement of the total size of the angel investment market, is difficult due to the fact that most angel investments are made on an individual basis, and thus typically are not subject to regulatory disclosure requirements. But estimates suggest that the total size of angel investment has long surpassed venture capital investment in the U.S. and increasingly in some other countries as well. For instance, survey estimates suggest the projected size of the total angel market in the U.S. grew from $\$ 17.6 \mathrm{~B}$ in 2009 to $\$ 24.1 \mathrm{~B}$ in $2014 .^{2}$ The estimated capital deployed by

\footnotetext{
2 These estimates are by Jeffery Sohl and the University of New Hampshire's Center for Venture Research:

http://paulcollege.unh.edu/sites/paulcollege.unh.edu/files/2009 Analysis Report. pdf and
} 
angel groups in Europe has almost doubled over the past five years, while in Canada, it almost tripled. ${ }^{3}$ Despite its rapid growth, we know very little about the role that angles play internationally and the type of firms in which they invest.

The appeal of angel investors is that they share many of the positive features of venture capitalists. They fund early-stage entrepreneurs, undertake intensive due diligence of potential investments, and serve as mentors and (sometimes) outside directors for the entrepreneurs (Kaplan and Stromberg, 2003; Wong, Bhatia and Freeman, 2009). But since angels invest their own money, they should be less prone to agency problems that have been documented for VC funds: for instance, fee-based compensation structures can lead to excessive fund raising (Metrick and Yasuda, 2010; Chung, et al., 2012) or sub-optimal investment and exit decisions (Gompers, 1995). The consequences of these agency problems may be periods of overfunding in certain sectors (Gompers and Lerner, 1999). Active involvement in the investments and close social ties between angels and entrepreneurs may help to overcome the lack of minority shareholder and legal protections that are important for the development of more decentralized capital markets: see, for example, La Porta, et al. (1998, 2002). Reflecting these patterns, governments are increasingly seeking to encourage angel investment (Wilson, 2015). The hope is to encourage alternative

https:/paulcollege.unh.edu/sites/paulcollege.unh.edu/files/webform/2014\%20An alysis\%20Report.pdf.

${ }^{3}$ According to data presented in reports from EBAN in Europe and NACO in Canada, which is collected from angel groups via surveys. 
mechanisms for funding new ventures and to improve the ecosystem for entrepreneurs.

Relying on an idiosyncratic and decentralized angel investment process, however, might lead to challenges of its own. Since angels are typically not professional investors, there is a worry that entrepreneurs will be exposed idiosyncratic funding risk, either because angels themselves might be subject to idiosyncratic liquidity shocks or because they might change their opinions more frequently about what projects to fund. In addition, angels might not be prepared to invest in truly disruptive or high growth projects, since they are usually more risk averse than institutional investors due to limited diversification. They also might not have the professional expertise to invest in more complex technologies. And finally, there is a concern that in countries that do not have the culture or infrastructure to support start-up investments, angels only waste their time and money with no real impact.

This paper seeks to understand the differences in the nature and consequences of angel investments across a variety of geographies with varying levels of venture capital markets and other forms of risk capital. We ask whether angel investors improve the outcomes and performance of the start-ups they invest in. Furthermore we want to understand whether and how the types of firms that seek angel funding vary with the overall entrepreneurial ecosystem in a country. For 
example, is the pool of investments that apply for angel funding less risky, more developed, or focused on different industries than those in places like the U.S.?

For that purpose, we examine the records of 13 angel investment groups based in 12 nations and with applicants for financing transactions from 21 nations, examining both the applicants that were considered and rejected and those that were funded. In order to differentiate the value added of angel groups from their ability to select good investments, we employ the type of regression discontinuity analysis we used in our earlier analysis of U.S. angel groups (this approach is similar to Kerr, Lerner and Schoar, 2014). We use discontinuities in the funding likelihood of startups that are based on cumulative level of interest around the deal on the part of the angel groups. This allows us to examine not only whether angel investors overall add value to the companies in which they invest, but also how their impact and the types of transactions undertaken varies with the development of the venture markets in these nations.

Our focus on angel groups has advantages and disadvantages. Many papers in the entrepreneurial finance literature rely on data-sets constructed of matched firms based on related few observables. In our setting, all firms seek financing from and achieve similar ratings by the same angel groups, and thus are much more homogeneous. But since these groups work collectively and were required to have a track record and systemized record keeping in order to be included in our study, they may be more successful and impactful than the typical individual angel. 
Our key findings from the analysis are two-fold. First, angel investors have a positive impact on the growth of the firms they fund, their performance, and survival. Start-ups funded by angel investors are $14 \%$ to $23 \%$ more likely to survive for the next 1.5 to 3 years and grow their employment by $40 \%$ relative to non-angel funded start-ups. Angel funding also effects the subsequent likelihood of successful exit, raising it by $10 \%$ to $17 \%$. Unlike in the U.S., however, having angel funding also seems to matter significantly for the ability of a firm to obtain follow-on financing. This result seems to suggest that angel groups outside the U.S. serve as an important accreditation or gateway for follow-on funding. In fact, the positive impact of followon funding does not vary when we interact the main effect with proxies for the entrepreneur-friendliness of the countries. This result is contrary to what Kerr et al (2013) found for the role of angel investments in the US. It might suggest that the availability of risk capital in the U.S. is more abundant and therefore start-ups have many different avenues of obtaining their initial seed funding, including VC funding. As a result, firms do not necessarily have to have had an angel round before getting funding from larger players. ${ }^{4}$

\footnotetext{
4 Using a sample of Canadian firms, Hellmann, Schure and Vo (2015) find that prior angel financing reduces probability of obtaining subsequent venture capital financing. However, their results are driven mostly by inexperienced angels and their analysis is based on a country with a relatively developed risk-capital market. By way of contrast, we collect data from a variety of countries and, from some of the most active angel groups within a particular country. Therefore, the differences in results might arise from the fact that our angel groups are quite sophisticated and experienced investors in their respective countries. See also Hellmann and Thiele (2014).
} 
Second, we find that the selection of firms that apply for angel funding is different across countries. In countries that have a less conducive entrepreneurial environment, companies seeking angel funding appear to be older and larger on average and are usually already revenue generating compared to applicants in more entrepreneurship-friendly countries. Yet despite their apparent greater maturity, the firms in these markets seek smaller amounts of funding. We proxy for the entrepreneur friendliness of a country with (1) the depth of the VC market as a fraction of GDP and (2) the number of regulatory procedures while incorporating a firm, taken from Djankov, et al. (2002). Given that these are countries with a less developed ecosystem for risk capital, it is difficult to believe that entrepreneurs in these countries have many other sources of capital and therefore only apply for funding at a later stage in their life cycle. Instead, the results suggest that firms seem to "self-censor" when they apply to angel groups in the less venture-friendly markets, reflecting the fact that the angel investors themselves are more risk-averse or less experienced in assessing very early-stage investments. The fact that despite the more mature stage of these firms, they receive less funding from the angels, underscores that the less favorable entrepreneurial investment climate in these countries. ${ }^{5}$

The plan of the paper is as follows. In Section 2, we describe the construction of the data set and the key institutions at work. In Section 3, we preview the sample

5 We cannot rule out that in countries with less developed entrepreneurship markets, the demand for capital is more constrained as well, for example, if there are more barriers to entry on the product market side. If start-ups believe that their growth opportunities or the speed at which they can expand is limited, they might demand smaller amounts of capital. 
and the regression discontinuity design that we employ. Section 4 presents the results regarding the impact of angel investment; and Section 5, those relating to the selection of firms into angel financing. The final section concludes the paper.

\section{Construction of the Data Set}

This section describes the process by which we constructed the dataset. We also provide a brief overview on the nature of angel investment groups worldwide.

To build the dataset, we began by contacting angel groups with whom we had personal connections. These included cases where we had previous interactions with groups in previous OECD studies, those in which former students played prominent roles, and alumni contacts via Harvard and MIT. In addition, we reached out to a number of associations and informal consortia of angels, such as the Angel Capital Association, to encourage participation in the study.

In each case, we required that the participating angel groups:

- Have been active investors for at least two years.

- Have (or be able to compile) records both on applicants that were funded and those that were considered and rejected.

- Have records about the degree of angel interest in potential transactions, or in one case, as discussed below, be able to reconstruct the level of such interest. These requirements eliminated many would-be participants from our effort. 
In all, we obtained data from 13 groups. In most cases, we signed a datasharing agreement, which confirmed that we would ensure the anonymity of the groups and the portfolio companies, and limited our ability to redistribute the data, but did not restrict our ability to undertake academic research using the data in an unfettered manner. The funds were base in Argentina, Australia, Belgium, Canada, China, Germany, Italy, Mexico, New Zealand, Switzerland, the United Kingdom, and the United States.

Angel groups included in the study range from smaller groups with a few members to larger groups with over 100 or more members. The membership models differ, from groups that are more open to those that are more selective. Some groups encourage new angels to join and provide training for these individuals to help them develop their skills and confidence in angel investing. Other groups are invitation only and have specific requirements regarding the background, experience and area of expertise of the angel investors.

The angel groups differ in terms of how they originated. Some groups were founded by angel investors but a number were created by business people and, in some cases, are linked with a university or business school. In addition, some of the angel groups were created with support from national or regional governments.

Most of the angel groups in the study invest in companies in technologyrelated sectors, including, in many cases, life sciences and clean tech. Some also invest 
in a much broader set of sectors including arts and entertainment, consumer goods, education, and food and beverage. The angel groups in the study also vary in their geographic focus. The majority of the angel groups invest primarily in companies in the local or nearby communities. However some invest more broadly across the country or, in some cases, across borders.

The structure and approach of the angel groups vary as do the selection processes. Many of the groups are run by professional staff but some are run by volunteer angels. However, in all cases, the angel groups have pitching events in which selected entrepreneurial teams are invited to present their company after which a decision is made, either as a group or by angels individually, whether to consider making an investment. As described in the next section, two of the groups do not have a voting process but other proxies were used to determine angel interest.

\subsection{Sample Selection}

The angel groups participating in the study are from a range of countries in Europe, Asia Pacific, Latin America and North America, each with very different funding landscapes. It is important to acknowledge that within each country, our selection methodology and criteria are likely to lead to us getting data from the more organized and prominent angel groups. This fact probably means that we are estimating the upper bound of the impact that angels can have in a country. But across countries, the selection procedure was similar, so it is unlikely that we have identified high-caliber angel groups in same markets and lower-tier ones in others. 
While the U.S. remains predominate in terms of the volume of venture capital and angel investment, angel investing, both individually as well as through groups, has grown in many other countries around the world (OECD, 2011). There are significant differences in the financial and regulatory environment across the countries covered in the study. For instance, the level of development of public markets and the formal venture capital sector may differ. Similarly, substantial differences exist in the administrative burdens not only of starting but also growing firms. There are also differences in regulation related to investment, which impact the incentives for institutional and individual investors to provide funding for startups. These include investment rules, barriers to cross-border investment, and securities legislation (Wilson and Silva, 2013).

It is unclear how these differences will affect the level of angel investment. If venture capital and angel investments are complements, the nations where venture activity is better developed might be also the places where angel investment is more effective. This complementarity might be driven by the fact that angel groups, after undertaking the initial financing, "hand off" their transactions to venture groups for subsequent financing: without a healthy venture sector, the companies may languish. If, on the other hand, venture capital and angel investments are substitutes-for instance, because both groups of investors are competing for the same transactiona well-developed venture market might "crowd out" angel investment or lead to angels funding less promising firms. Similarly, the presence of high regulatory 
barriers to entrepreneurship may make angel investments either more or less effective. We will examine the impact of a number of these differences in the analyses below.

One aspect, which we will not examine, is the numerous efforts by policy makers to facilitate the development of angel investments. In some countries, policy makers have launched co-investment funds to address the seed/early stage equity financing gap and to help develop and professionalize the angel investment market. Other countries have put various tax incentives in place to encourage angel investments, mostly at the national level but sometimes at the state or provincial level. Other initiatives include investor readiness and investor training programs, as well as the direct funding of incubators, accelerators, and other matchmaking services. Most of these efforts are of quite recent vintage, but will present opportunities for study in later years.

\section{Data Description and Regression Discontinuity Design}

\subsection{Data Description}

Table 1 presents descriptive statistics for the final sample of 1682 deals that resulted from our data collection effort: a total of 295 funded and 1287 non-funded companies. Because our sample consists of small, privately held firms, and the incomplete record-keeping by the angel groups, determining the outcomes of these investments was challenging. We proceeded in the following manner: 
1. Angel group information: The angel groups in many cases tracked key information about the firms that they had funded. Coverage of firms that the angel groups had not funded, however, was much poorer.

2. Internet searches. We examined the website URLs that were provided to the angel groups at the time the companies sought financing. In addition, we sought to identify such company websites (or other websites with relevant information), using Google, Baidu, and LinkedIn searches, employing the company and founder names as search elements. Finally, we used the domains suggested by the email addresses of the founders to identify relevant websites. These sites yielded information about, among other information, the founders, firm status, employment, and investors. When they encountered foreignlanguage sites, we used students or Harvard Business School staff researchers with the requisite language skills to examine the websites in hopes of gleaning relevant information.

3. Corporate and financing databases. We turned to the two primary corporate databases with broad coverage of international entrepreneurial firms, CapitallQ and Bureau van Dijk's Orbis database. These entries yielded information about the founder, firm addresses, employees, number of and total amount in investment rounds, and firm outcomes. We also examined the specific databases of initial public offerings and acquisitions compiled by Thomson Reuters. All financing sums were in (or were converted into using contemporaneous exchange rates) U.S. dollars. 
4. Venture capital-specific databases. We also examined databases that cover venture capital financings. These were Thomson Reuters' VentureXpert, CrunchBase, and the Emerging Markets Private Equity Association database. These contained data on financings raised, founders, and subsequent changes in firm status.

5. News stories. We searched on company name for relevant news stories in the Factiva database. This provided information about the company status, exit events, and the founders.

6. Patents. We collected information about U.S. patent awards through the U.S. Patent and Trademark Office (USPTO) website, as well as the Thompson Innovations database. While the latter database has a large amount of information about patent filings worldwide, we focused solely on U.S. awards to ensure consistency.

7. Direct contacts: We contacted the companies directly via email and cellular phone (contact information was typically gathered by the angel groups as part of the application process). In order to undertake the email and phone contacts, we employed students with the necessary language skills.

Due to the challenges in gathering data, we focus on a relatively modest set of outcomes, not seeking to gather information that would be likely to be perceived as too proprietary or complex to gather in a short call (e.g., balance sheet and income statement information, or valuation data). Instead, we focus on the following 
measures (all data was collected over the period between February and October 2014, and was for the time of our contact with the firm, unless otherwise noted):

- Survival of the firm.

- Survival of the firm for at least 18 months after the original application to the angel group (to control for the fact that these firms' initial financing occurred at various points in time, and hence they had different times to survive until 2014).

- A successful exit, defined following the earlier literature (e.g., Hochberg, Ljungqvist, and Lu, 2007) as an initial public offering or an acquisition. While ideally we would distinguish between acquisitions at attractive and unattractive valuations, given data limitations, this was not feasible.

- Employment at the firm.

- The number of patents awarded to the firm by the USPTO, both within 18 months of the original application to the angel group and at the time of the final observation.

- Whether any of the founders were still with the company, and whether any of the founders were still CEO of the firm.

- Whether the firm received any subsequent financing and any venture capital financing specifically.

- The total amount of subsequent financing raised.

Table 1 shows that the average applicant had ten employees at the application stage, with three of them representing the firm's management team. It was also 
seeking to raise US $\$ 1.2$ million from the angel group. These numbers are somewhat smaller relative to what Kerr, Lerner and Schoar (2014) reported when relying solely on the U.S. data. This information suggests that entrepreneurial firms outside of the U.S are smaller at the application stage. The distribution of the venture's stage of development is heavily skewed towards firms that are already marketing their products and revenue-generating firms. These results imply that firms apply for angel financing when they have an established business concept and already have made progress in the development of their products or services. In fact, $40 \%$ of ventures applying for funding already generated some revenue.

We also observe substantial differences between funded and non-funded deals. In particular, funded ventures tend to be significantly larger and are more likely to be revenue generating at the time of the application. In addition, we can observe that the industry distributions of funded and non-funded deals are also very different, with greater representation among the funded of biomedical and electronics firms, and less of Internet and e-commerce concerns. These results might be driven by cross-country composition of our sample if angels in different countries face different sets of deals. We will turn to a composition analysis later in the paper.

\subsection{Identifying discontinuities}

The key ingredient of our identification strategy is constructing a measure of angel interest that reflects the fact that angel group provide funding with a certain degree of randomness. Following Kerr, Lerner, and Schoar (2014), we obtain 
information on voting patterns of each of the angel groups to construct such a variable. For each group, we collect information on the number of angels that expressed interest in a particular deal, as well as on the total number of angels that were able to evaluate that deal. Having this information, we proceed to a construction of our group-specific angel interest measure.

We observe two key voting patterns across our sample groups. For the first type of groups, the number of angels that participate in deal evaluation remains relatively constant. In these cases, we use a number of angels that were interested in a deal as our measure of angel interest. For the second type of groups, the total number of angels varies across deals. Usually, we observe growth in a total number of members because the group is expanding over time. In these cases, the absolute number of interested angels is not very informative about the overall level of interest. Therefore, for these deals, we calculate a share of angels that expressed interest and use this number of our measure of angel interest.

In two cases, the information on voting patterns was not available. In the first case, angels use a scoring system on a scale of 0-5 when evaluating potential deals. For this group, we use an average score that a venture received as a measure of angel interest. In the second case, we asked group's founder to evaluate the level of interest for a particular deal on a scale of $0-5$. We realize that this measure might be biased, because it is subjective and is reported after the funding decision was made. The 
results were robust to the exclusion of this group's transactions form the analysis below.

Having defined a group level measure of interest, we proceed to the identification of discontinuities in probability of being funded as a function of angel interest. As our sample groups do not have explicit funding cutoffs, we must identify breaks using observed voting behavior. We follow the procedure described in Kerr, Lerner, and Schoar (2014). For each group we identify a "funding discontinuity": the critical level of interest that translates into a substantial increase in the funding probability. Once such a level of interest is determined, we generate a narrow sample of ventures that are either just above or just below the funding discontinuity.

Figure 1 illustrates the process of identifying the funding discontinuity and the construction of the border sample for one of the groups that participated in the study. First, we plot the probability of being funded by an angel group together with a measure of angel interest (the share of angels interested in this particular case). The likelihood of obtaining funding generally increases with angel interest, as expected. Second, we observe that the biggest increase in funding probability occurs around an interest level of $30 \%$. In particular, when the level of interest crosses $30 \%$, the funding probability increases dramatically: from $2 \%$ to $15 \%$. We identify this threshold as the funding discontinuity and the firms that had similar levels of interest $(20 \%-40 \%)$ as a border sample. We refer to deals that obtained interest levels of $20 \%-30 \%$ as "below the border" deals and to the deals that obtained interest levels 
of $30 \%-40 \%$ as "above the border" deals. This process is repeated for every group that participated in our study.

Table 2 provides an overview of the construction of the border sample. For each group it presents the indication of angel interest used to determine the discontinuity, the range that in which the border group fell, the cutoff employed, and the sample size.

In each case, we also present the difference in the probability of funding for groups in the border sample above and below and discontinuity. We present these differences on an absolute and relative basis. For instance, for group 1, the mean probability of being funded if in the border sample and below the cutoff is $2 \%$, while if in the sample and above the cutoff it is $15 \%$, for an absolute difference of $13 \%$ and a relative difference of $750 \%$. We explore below the robustness of the analysis to alternative definition of the border sample.

Our central identifying assumption is that characteristics of ventures are similar around the funding discontinuity. In other words, certain ventures fell above the funding discontinuity only because they randomly obtained a slightly higher level of interest. It is reasonable to assume that there is enough heterogeneity in angels' preferences and their subjective evaluations such that their aggregated level of interest exhibits some degree of randomness and does not perfectly match with 
underlying venture's quality. In addition, we verify empirically below that above the border and below the border ventures do not differ in their observed characteristics.

\subsection{Description of "threshold deals"}

Table 3 presents the descriptive statistics for our "border" sample of 578 deals. We have 343 ventures below the border discontinuity and 235 ventures above the border. The difference in number reflects the fact that the funding discontinuities are group-specific and the within-group distribution of ventures around the border is not always even. We also observe that the venture characteristics in the border sample are similar to those of the entire sample as presented in Table 1.

Table 3 is also informative about incomplete data in our border sample. As it shows, we were not able to obtain a complete set of characteristics for every single venture: this is especially true for the amount of financing that a venture was seeking. We observe that distribution of "gaps" is not different around the funding discontinuity. In fact, we have slightly more information about the "below the cutoff" ventures, which is consistent with having more observations in total for this set of firms.

We perform two sets of analysis to verify comparability of the two border groups. First, we look into the simple difference in means between the groups. The results show that ventures above the border discontinuity have slightly larger 
management teams and exhibit a different distribution of the stage of firm development.

These differences might arise, however, from the fact that the border sample combines a number of angel groups that face quite different sets of deals. To overcome this issue, we demeaned venture's characteristics one by one using its group-level means and rerun our balance tests. The results indicate that none of the demeaned differences are statistically significant. Therefore, we conclude that the results from the first test were driven by differences across angel groups. After accounting for these differences, the border firms are very comparable in terms of firm size, as well as industry and stage compositions. ${ }^{6}$

A final concern might be that we have much more information about the outcomes of transactions above the discontinuity than those below it. In an unreported analysis, we compare the availability of outcome data for the 578 firms in the border sample. We have data on eleven different outcomes (e.g., number of patents, whether the firm was acquired): seven outcomes have full coverage, with data on all the firms, and four outcomes have partial coverage. For the cases with

\footnotetext{
${ }^{6}$ In an unreported analysis, we undertook "enhanced demeaning". Instead of running demeaned t-tests, we ran regressions of firm's characteristics on "above the cutoff" dummy and fixed effects. The coefficient on the "above the cutoff" dummy was never significant, which means that after controlling for fixed effects, the status relative to the cutoff was not correlated with firm's characteristics. This result implies that the firms above the cutoff and below the cutoff have similar characteristics, as we argue above.
} 
partial outcome data, the coverage is nearly identical for the groups above and below the discontinuity. The one exception is employment, where the coverage is substantially higher for the above the cutoff firms (66\%) than those below (45\%). Therefore, it is unlikely that our key results are driven by the differences in the availability of information about the outcomes across firms.

\section{Results of Regression Discontinuity Analysis}

Having established the presence of a discontinuity, we now go further towards exploring the relationship between angel funding and firm outcomes relationship by using a regression discontinuity approach (Lee and Lemieux, 2010). As we have argued in Section 3, there exists a discrete jump in the probability of venture funding as interest accumulates around a deal.

We first compare the outcomes of firms in the bands above and below the discontinuities. As we showed in Section 3, these firms look similar in terms of their characteristics prior to approaching the angel group. But the outcomes, as we will see below, are quite different.

Table 4 summarizes the key findings. The firms above the discontinuity are significantly more likely to survive in the short and longer run, as well as to undergo a successful exit. For instance, the probability of a successful exit is four times greater (25\% vs. $6 \%$ ). These firms are also significantly more likely to raise subsequent financing. 
Comparing the results to those found in Kerr, Lerner, and Schoar (2014), there is a similar pattern in that firms that are above the discontinuity are more likely to survive, as well as (more weakly) to undergo a successful exit. The U.S. firms studied in the earlier paper that were above the angel financing discontinuity were more likely to patent, an effect not seen here, perhaps reflecting the relative ineffectualness of formal intellectual property protection in many of these markets or the barriers to small non-U.S. firms in seeking U.S. protection. Finally, the U.S. firms did not display a significantly higher probability of raising additional financing, unlike these firms. This may reflect the relative immaturity of many of the markets in this study, where accessing early-stage financing may be more of a struggle.

Another important way to look at the division of outcomes is to examine how these vary by nationality of the firm. Again, we focus on firms around the funding discontinuity. We examine two partitions: whether the angel group (not the applicant firm $)^{7}$ is located in a nation with above or below the median level in terms of venture capital activity (computed as venture capital investment as a fraction of GDP, as of 2010, compiled from various national and regional venture and private equity

\footnotetext{
7 We decided to focus on 12 countries the groups come from and not the 21 countries that firms comes from, because we find that most of the investment is local, i.e., American groups invest primarily into American firms, etc. There are a very small number of foreign investments by these groups, driven by a few organizations in small nations. There is consequently not enough variation to analyze both the firm's country and the angel group's country simultaneously. When we repeat the analysis using firm's country instead, the analysis does not yield any different results.
} 
associations), and in the barriers to entrepreneurial activity, measured by the number of steps required to start a business, as reported by Djankov, et al., (2002).

It is worth highlighting that many of the measures of the entrepreneurial environment across nations are highly correlated. For instance, across the 12 nations in which angel groups are located, the correlation between one of the measures we use, the number of steps to form a business, is strongly negative with such metrics as the Heritage Foundation index of property rights in 2004 (-0.77), GDP per capita in 2010, as reported by the World Bank (-0.71), and the creditor rights index in Djankov, McLiesh, and Shleifer (2007) (-0.43), and positively correlated with the estimated cost of starting a business from World Bank's 2010 Doing Business report (0.80). Similarly, there is a strong negative correlation between two measures that we use here $(-0.47)$.

We picked up these variables because we see these as proxies for the overall entrepreneurship-friendliness of the country. We should not be seen as arguing that these analyses "identify" a specific channel. When we repeat these analyses using the alternative measures-e.g., GDP per capita, the creditor rights measure, or the index of property rights-we get similar results. The correlations across the various country-level variables (with each country as an observation) are reported in Appendix Table I. All variables are defined in Appendix Table II. 
We see in Table 5 that success does vary with the national environment. In nations with above the median level of venture capital activity, firms are more likely to have a successful exit, to experience growth in employment and patenting, and to raise additional financing. In countries that are more entrepreneur friendly (i.e., those requiring fewer steps to start a business), firms are more likely to survive, to patent more, and to raise additional financing. Interestingly, in these nations, founders are less likely to remain with the firm, which may reflect greater pressures from outside financiers to professionalize these firms' managements (Hellmann and Puri, 2002). ${ }^{8}$

Having established the presence of these differences in univariate comparisons, we now turn to regression discontinuity analyses. Table 6 documents the probability that a firm raises angel financing, as a function of its position relative to the funding discontinuity. Thus, the analysis formally tests whether there is a significant discontinuity in funding around the thresholds for the ventures considered by these groups. The dependent variable is an indicator variable that equals one if the firm received funding and zero otherwise. The primary explanatory variable is an indicator variable for the venture being above or below the discontinuity.

Column 1 presents a regression with just a constant, while successive columns control for angel group fixed effects, year fixed effects, and industry fixed effects, as

\footnotetext{
${ }^{8}$ In later tables, we include controls for angel groups and industry, among other considerations, to control for unobserved differences.
} 
well as other observed characteristics of the ventures at the time of the application date, such as the stage of development, employment, management team size, amount of financing sought, and a number for patents awarded by USPTO. As in Tables 3 and 4, we have 578 deals that are distributed above and below the discontinuity. (When we employ the venture-specific variables, the sample size drops considerably to 307.)

We find that there is a statistically and economically significant relationship between funding likelihood and being above the funding threshold: a firm's presence above the border increases the funding likelihood by between 18 and 30\%. Clearly, the border line designation is not a perfect rule-and this fuzziness will limit below how strongly we can interpret the regression discontinuity—but it does signify a very strong shift in funding probability among ventures that are ex ante comparable, as shown in Tables 2 and 3.

Tables 7 and 8 then present the regression analyses of the impact of angel financing on firm outcomes. Again, we use in each case the sample of firms near the cutoff, and run specifications using the entire (or almost the entire) sample (when employing angel group, year, and industry fixed effects) and the smaller 307-firm sub-sample (when using the venture-level controls). We examine a subset of the outcomes considered in Tables 3 and 4.

In Table 7, we use whether the firm received angel financing as the key independent variable; in Table 8, whether the firm was above the funding discontinuity. The results are 
quite similar across the two analyses: in each case, the angel-funded (or more likely to be funded) ventures are more likely to survive, to have a successful exit, and to raise subsequent financing, as well as to hire additional employees.

The results are somewhat more consistently statistically significant when the regression discontinuity approach is employed (that is, in Table 8). For example, in the first specification of Table 8, Panel A, moving from below to above the cutoff increases the probability of venture's survival in the years after the application for financing by $18 \%$, relative to a mean of $73 \%$. In the fifth regression, moving from below to above the cutoff increases the probability of IPO or acquisition by $16 \%$, relative to a mean of $15 \%$. In the seventh and eighth regressions moving from below to above the cutoff increases increase the number of employees by approximately $40 \%$. In the fifth regression in Panel B, moving from below to above the cutoff increases the probability of raising additional financing by $16 \%$, relative to a mean of $29 \%$.

As discussed above, one concern is that the results are an artifact of the particular border sample chosen. In an unreported set of regressions, we repeat the analysis in Table 8, now using more narrow ranges than those denoted in Table 2: for each group we look at a border sample that is one-half the size of the reported analysis. For instance, for Group 1, we narrow the border sample to ventures with a level of interest between 25\% (instead of 20\%) and 35\% (instead of $40 \%$ ). When we use this smaller sample (for instance, the unreported version of the first regression 
in Table 8 has 226 observations rather than 568 observations in the reported analysis), significance levels fall somewhat, but the results are qualitatively similar.

We finally consider how these outcomes vary with the national environment: that is, whether the impact of angel investment is different in settings which are more entrepreneur-friendly or where venture activity is more prevalent. To undertake these analyses, we repeat the analyses in Table 8, adding as independent variables one of the two measures of the national environment we use above and an interaction between this measure and the dummy variable indicating whether the firm was above the funding discontinuity.

The results, reported in Table 9, are striking. As in Table 8, the increased likelihood of angel financing has a strongly positive impact on outcomes. A more entrepreneur-friendly environment also translates into a greater probability of survival and of subsequent financing. More venture capital activity is associated with a greater probability of subsequent financing, but a lower chance of survival. But most interesting are the interaction effects: in all but two regressions, the interaction between the national environment and being above the cutoff for angel financing is insignificant. This suggests the positive impact of angel financing on the development of portfolio firms remains consistent across the nations under study, regardless of the level of venture activity and the entrepreneur-friendliness of the environment. ${ }^{9}$

\footnotetext{
${ }^{9}$ Due to the concerns discussed above about the broad range of ways in which in the countries of the angel groups can be characterized, we also take an alternative approach to characterizing nations. We run a principal components analysis using a
} 


\section{Results Regarding Sample Selection}

The stark differential impact that angel funding has in the US compared to other countries might point to the fact that the type of firms that select into angel funding are different between countries. In particular, one more mechanical story would be that in Europe, younger or less mature firms get angel funding and therefore angels have a greater role in follow on funding. For that purpose, we analyze to what extent do the criteria for funding employed by angels vary with the national setting? We first undertake univariate comparisons of the companies applying to the angel groups; and then also replicate our results in a regression analyses format. We show that the mechanical selection story mentioned above does not explain our results.

We begin by examining all the 1682 firms which were considered by the angel groups; we then turn to the 578 firms in our cutoff sample. In Table 10, we compare the two samples of firms - whether funded or not-in nations with above and below the median number of steps to start a business, as well as those with above and below the median venture capital to GDP ratio.

number of key country characteristics that capture the level of economic and financial development, as well as the costs of doing business. We find that the first component explains $63 \%$ of the variation in the country characteristics. Moreover, it loads strongly positively on the development variables such as GDP per capita, index of property rights, and VC/GDP ratio. The first principal component also loads strongly negatively on a number of variables that capture costs of doing business, including the variable that we use in the paper. We repeat the analyses in Tables 9 and 11, using the first principal component score, as well as the other measures, in lieu of the national characteristics. The results are very similar to the reported ones. 
We find a striking pattern: when we look at the entire population of applicants in Panel A, the firms look very different across the nations. In environments that were less entrepreneur friendly or where the venture market was less well developed, the firms had more employees (though smaller management teams) and were less likely to be in the early stages of development. These companies also were seeking a smaller amount of funding. In part, these differences may reflect industry composition: for instance, the firms in these less venture friendly markets were more likely to be Internet and e-commerce firms, which may be asset-light. But these differences may reflect choices by entrepreneurs about which start-ups can realistically succeed and raise funding in these markets.

Turning in Panel B to the subset of firms in the cutoff sample, we see that very similar patterns hold. The firms seriously considered for funding in less venturefriendly markets tended to be larger, at a later stage of development, and to seek less funding. While these patterns are seen in the choice of firms under careful scrutiny of the groups, it also reflects (as we saw in Panel A), the overall pool of applicants for funding.

Having demonstrated these patterns in a univariate analysis, we now turn to a regression analysis. Here we use the entire sample of 1682 firms seeking financing from these angel groups (i.e., the same sample in Panel A of Table 10). We compare the firms on the basis of various ex ante characteristics, including employment, 
management team size, the amount of financing sought, and the firm's stage of development. We control for whether the firm ultimately received angel financing, the characteristics of the national venture environment, and the interaction between these two factors.

Table 11 shows that there are substantial differences across countries. We see that the angel-funded companies tend to have more employment and larger management teams, to seek more funding, and are less likely to be in the early stages. In Panels A and B, we see that in nations which are less entrepreneur friendly, the ventures seeking angel financing tend to have more employees, smaller management teams, and are less likely to be in the early stages. In nations with less venture funding (Panel C and D), the ventures have similar features: they tend to have smaller management teams, to seek more funding, and are less likely to be in the early stages. Unlike those in the entrepreneur-unfriendly nations, though, they tend to have fewer employees.

What is more striking is the almost universal lack of significance of the interaction terms: only one of the 12 interactions is significant at the $5 \%$ confidence level, and two at the $10 \%$ level. (The large coefficients on the interaction terms in Panels $C$ and $D$ reflects the fact that the VC/GDP ratio is quite modest.) It appears that while the mixture of companies funded by angel groups shows distinct patterns across nations, this reflects the companies applying to seek angel financing, rather than their choices within the set of applicants. Consistent with a story in which firms 
rationally anticipate which types of deals will be attractive to angel investors in that country, in markets with a less developed venture environment, firms appear to set a higher bar when deciding whether to apply for angel financing.

\section{Conclusion}

Angel investors are attracting increasing interest from financial economists and policy makers alike, reflecting their apparent ability to solve some of the information problems that other types of investors seem to have problems solving . This paper examines a cross-section of 13 angel groups who considered transactions across 21 countries, exploiting information both on transactions they funded and those they passed on, as well as the groups' evaluations of the potential transactions.

We find that, consistent with the evidence from the United States, angel investors have positive impact on the growth, performance, and survival of the firms they fund. The positive impact of angel financing on portfolio firms remains consistent across the nations under study, regardless of the nation's level of venture activity and its entrepreneur friendliness. However, international angel funds, different form U.S. angels, positively enhance the ability of the funded firms to obtain follow-on financing. This suggests that angels have a more important gatekeeper or accreditation role in countries outside the US. At the same time we show that there is self-selection of firms that are funded by angels in less developed venture environments: Only more mature businesses, with more proven cash flows and seeking fewer funds, apply to angels. This might be the outcome of self-censoring by 
very early stage start-ups who do not expect to receive funding from angel groups, who themselves might be more risk averse or inexperienced in making very earlystage investments.

This work suggests a variety of avenues for future research. First, we have suggested that one channel by which angel investors adapt to the changing investment environment across nations is by selecting different transactions (though this is at least partially determined by differences in the mixture of firms applying for funding). It would be interesting to examine whether angel groups adjust in different ways, whether by varying the contracts that they enter into with the entrepreneurs they fund (as Lerner and Schoar (2005) document that venture capital and private equity funds do) or by adjusting the intensity of oversight provided. Another fertile area for research would examine the evolution of the role of these investors in markets such as China and India, where venture capitalists (as opposed to the more established private equity funds) appear to have been gaining traction in recent years. Differences in practices and impact of angel groups located in varying regions in particular countries may provide another fertile area for exploration. 


\section{References}

Chung, Ji-Woong, Berk A. Sensoy, Léa Stern, and Michael S. Weisbach, (2012), "Pay for Performance from Future Fund Flows: The Case of Private Equity," Review of Financial Studies, 25, pp. 3259-3304.

Djankov, Simeon, Rafael La Porta, Florencio Lopez-de-Silanez and Andrei Shleifer, (2002), "The Regulation of Entry", Quarterly Journal of Economics 117, pp. 1-37.

Djankov, Simeon, Caralee McLiesh, and Andrei Shleifer, (2007), "Private Credit in 129 Countries," Journal of Financial Economics 12, pp. 77-99.

Gompers, Paul, (1996), "Grandstanding in the Venture Capital Industry," Journal of Financial Economics, 42, pp. 133-156.

Gompers, Paul and Josh Lerner, (1999), "Money Chasing Deals?: The Impact of Fund Inflows on the Valuation of Private Equity Investments," Journal of Financial Economics, 55, pp. 281-325.

Hellmann, Thomas and Manju Puri, (2002), "Venture Capital and the Professionalization of Start-Up Firms: Empirical Evidence," Journal of Finance, 57, pp. 169-197.

Hellmann, Thomas and Veikko Thiele, (2014), "Friends or Foes? The Interrelationship between Angels and Venture Capital Markets," Journal of Financial Economics, 115, pp. 639-653.

Hellmann, Thomas, Paul Schure, and Dan Vo, (2015), "Angels and Venture Capitalists: Complements or Substitutes?," Working Paper, University of British Columbia

Hochberg, Yael V., Alexander Ljungqvist, and Yang Lu, "Whom You Know Matters: Venture Capital Networks and Investment Performance," Journal of Finance. 52 (2007), pp. 251-301.

Kaplan, Steven N. and Per Strömberg, "Financial Contracting Meets the Real World: Evidence from Venture Capital Contracts," Review of Economic Studies, 70 (2003), pp. 281-315.

Kerr, William R., Josh Lerner, and Antoinette Schoar, "The Consequences of Entrepreneurial Finance: A Regression Discontinuity Analysis," Review of Financial Studies, 27 (2014), pp. 20-55.

La Porta, Rafael, Florencio Lopez-de-Silanes, Andrei Shleifer, and Robert Vishny, "Law and Finance," Journal of Political Economy 106 (1998), pp. 1133-1155. 
La Porta, Rafael, Florencio Lopez-de-Silanes, Andrei Shleifer, and Robert Vishny, (2002), "Investor Protection and Corporate Valuation," Journal of Finance 57, pp. $1147-1170$.

Lerner, Josh and Antoinette Schoar, (2005), "Does Legal Enforcement Affect Financial Transactions?: The Contractual Channel in Private Equity," Quarterly Journal of Economics, 120, pp. 223-246.

Lee, David S. and Thomas Lemieux, (2010), "Regression Discontinuity Designs in Economics," Journal of Economic Literature, 48, pp. 281-355.

Metrick, Andrew and Ayako Yasuda, (2010), "The Economics of Private Equity Funds," Review of Financial Studies, 23, pp. 2303-2341.

Organisation for Economic Cooperation and Development, (2011), Financing HighGrowth Firms: The Role of Angel Investors, Paris: OECD.

Organisation for Economic Cooperation and Development, (2016), Financing SMEs and Entrepreneurs Scoreboard, Paris: OECD.

Singer, Slavica, Jose Ernesto Amoros, and Daniel Moska, (2015), GEM 2014 Global Report, London: Global Entrepreneurship Research Association.

Wilson, Karen and Filipe Silva, (2013), "Policies for Seed and Early Stage Finance," Science, Technology and Innovation Directorate Policy Paper \#9, Paris: OECD.

Wilson, Karen E., (2015), "Policy Lessons from Financing Young Innovative Firms", Science, Technology and Innovation Directorate Policy Paper \#24, Paris: OECD.

Wong, Andrew, Mihir Bhatia, and Zachary Freeman, (2009), "Angel Finance: The Other Venture Capital." Strategic Change. 18 (7-8), pp. 221-230. 
Figure $1 \quad$ Voting Pattern of a Representative Group

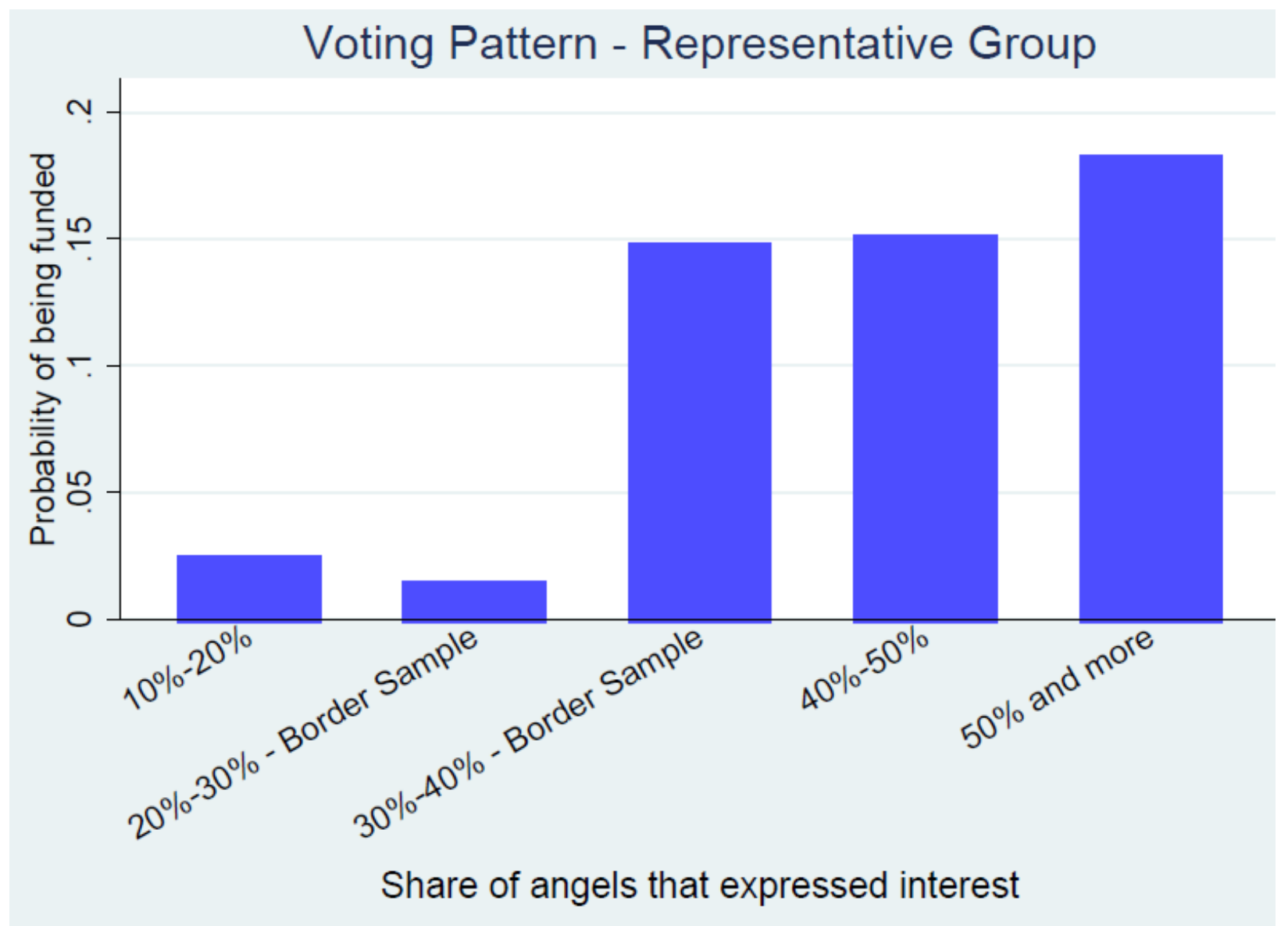


Table 1 - Descriptive Statistics

\begin{tabular}{|c|c|c|c|c|}
\hline Venture's Characteristics & Full sample & $\begin{array}{c}\text { Funded } \\
\text { ventures }\end{array}$ & $\begin{array}{c}\text { Non-Funded } \\
\text { ventures }\end{array}$ & Funded vs. Non-funded \\
\hline Employment & $\begin{array}{c}9.939 \\
(22.15)\end{array}$ & $\begin{array}{c}13.29 \\
(33.72)\end{array}$ & $\begin{array}{c}9.181 \\
(18.49)\end{array}$ & $\begin{array}{c}4.109 * * * \\
(1.542)\end{array}$ \\
\hline Management team size & $\begin{array}{c}3.391 \\
(1.783)\end{array}$ & $\begin{array}{c}3.799 \\
(1.848)\end{array}$ & $\begin{array}{c}3.297 \\
(1.755)\end{array}$ & $\begin{array}{c}0.502 * * * \\
(0.121)\end{array}$ \\
\hline Financing sought (USD, thousands) & $\begin{array}{c}1,186 \\
(2,868)\end{array}$ & $\begin{array}{c}1,381 \\
(3,955)\end{array}$ & $\begin{array}{c}1,140 \\
(2,557)\end{array}$ & $\begin{array}{c}240.5 \\
(193.4)\end{array}$ \\
\hline Stage of development & & & & \\
\hline Initial Idea & $\begin{array}{c}0.186 \\
(0.389)\end{array}$ & $\begin{array}{c}0.119 \\
(0.325)\end{array}$ & $\begin{array}{c}0.201 \\
(0.401)\end{array}$ & $\begin{array}{c}-0.0815 * * * \\
(0.0266)\end{array}$ \\
\hline Marketing and development & $\begin{array}{c}0.422 \\
(0.494)\end{array}$ & $\begin{array}{c}0.412 \\
(0.493)\end{array}$ & $\begin{array}{c}0.424 \\
(0.494)\end{array}$ & $\begin{array}{c}-0.0124 \\
(0.0339)\end{array}$ \\
\hline Revenue generating & $\begin{array}{c}0.392 \\
(0.488)\end{array}$ & $\begin{array}{c}0.469 \\
(0.500)\end{array}$ & $\begin{array}{c}0.375 \\
(0.484)\end{array}$ & $\begin{array}{c}0.0939 * * * \\
(0.0335)\end{array}$ \\
\hline Industry & & & & \\
\hline Biopharma, cleantech and healthcare & $\begin{array}{c}0.141 \\
(0.348)\end{array}$ & $\begin{array}{c}0.231 \\
(0.422)\end{array}$ & $\begin{array}{c}0.117 \\
(0.321)\end{array}$ & $\begin{array}{l}0.114 * * * \\
(0.0221)\end{array}$ \\
\hline Computers, electronics and measurement & $\begin{array}{c}0.147 \\
(0.354)\end{array}$ & $\begin{array}{c}0.190 \\
(0.393)\end{array}$ & $\begin{array}{c}0.130 \\
(0.336)\end{array}$ & $\begin{array}{c}0.0599 * * * \\
(0.0225)\end{array}$ \\
\hline Financial, educational and professional services & $\begin{array}{c}0.0937 \\
(0.291)\end{array}$ & $\begin{array}{c}0.108 \\
(0.312)\end{array}$ & $\begin{array}{l}0.0976 \\
(0.297)\end{array}$ & $\begin{array}{c}0.0108 \\
(0.0194)\end{array}$ \\
\hline Internet and e-commerce & $\begin{array}{c}0.183 \\
(0.386)\end{array}$ & $\begin{array}{l}0.0983 \\
(0.298)\end{array}$ & $\begin{array}{c}0.217 \\
(0.412)\end{array}$ & $\begin{array}{c}-0.118 * * * \\
(0.0254)\end{array}$ \\
\hline Technology, media and telecommunication & $\begin{array}{c}0.0985 \\
(0.298)\end{array}$ & $\begin{array}{l}0.0881 \\
(0.284)\end{array}$ & $\begin{array}{c}0.106 \\
(0.307)\end{array}$ & $\begin{array}{c}-0.0174 \\
(0.0196)\end{array}$ \\
\hline Other & $\begin{array}{c}0.337 \\
(0.473)\end{array}$ & $\begin{array}{c}0.285 \\
(0.452)\end{array}$ & $\begin{array}{c}0.334 \\
(0.472)\end{array}$ & $\begin{array}{l}-0.0491 \\
(0.0303)\end{array}$ \\
\hline Observations & 1,682 & 295 & 1,287 & \\
\hline
\end{tabular}

Table presents the descriptive statistics of the entire set of 1,682 deals. Column 1 shows means and standard errors of ventures characteristics for the full sample. Columns 2 and 3 present information for funded and non-funded ventures separately. Column 4 tests for the equality of the means between funded and non-funded ventures and presents the differences between the means. $* * *$ and $* * *$ denote statistical significance at $10 \%, 5 \%$ and $1 \%$ levels respectively. 
Table 2: Definitions of interest measures and cutoffs across groups

\begin{tabular}{|c|c|c|c|c|c|c|}
\hline Group & Angel interest measure & $\begin{array}{l}\text { Around } \\
\text { the border } \\
\text { range }\end{array}$ & Cutoff & $\begin{array}{c}\text { Border } \\
\text { sample size }\end{array}$ & $\begin{array}{l}\text { Absolute funding } \\
\text { probability change } \\
\text { - above the cutoff } \\
\text { vs. below the } \\
\text { cutoff }\end{array}$ & $\begin{array}{l}\text { Relative funding } \\
\text { probability change } \\
\text { - above the cutoff } \\
\text { vs. below the } \\
\text { cutoff }\end{array}$ \\
\hline 1 & $\begin{array}{l}\text { Share of angels that } \\
\text { expressed interest }\end{array}$ & $20 \%-40 \%$ & $30 \%$ & 107 & $13 \%$ & $750 \%$ \\
\hline 2 & $\begin{array}{l}\text { Subjective measure of } \\
\text { interest ( } 1-5 \text { scale })\end{array}$ & $3-4$ & 3.5 & 51 & $41 \%$ & $232 \%$ \\
\hline 3 & $\begin{array}{l}\text { Number of angels that } \\
\text { expressed interest }\end{array}$ & $1-9$ & 5 & 41 & $44 \%$ & $218 \%$ \\
\hline 4 & $\begin{array}{l}\text { Number of angels that } \\
\text { expressed interest }\end{array}$ & $5-14$ & 10 & 20 & $63 \%$ & $*$ \\
\hline 5 & $\begin{array}{l}\text { Number of angels that } \\
\text { expressed interest }\end{array}$ & $5-14$ & 10 & 29 & $16 \%$ & $245 \%$ \\
\hline 6 & $\begin{array}{l}\text { Number of angels that } \\
\text { expressed interest }\end{array}$ & $1-9$ & 5 & 30 & $63 \%$ & $415 \%$ \\
\hline 7 & $\begin{array}{l}\text { Average score given } \\
\text { by angels ( } 1-5 \text { scale })\end{array}$ & $3-4$ & 3.5 & 76 & $9 \%$ & $250 \%$ \\
\hline 8 & $\begin{array}{l}\text { Share of angels that } \\
\text { expressed interest }\end{array}$ & $70 \%-90 \%$ & $80 \%$ & 22 & $23 \%$ & $264 \%$ \\
\hline 9 & $\begin{array}{l}\text { Share of angels that } \\
\text { expressed interest }\end{array}$ & $60 \%-80 \%$ & $70 \%$ & 21 & $23 \%$ & $*$ \\
\hline 10 & $\begin{array}{l}\text { Number of angels that } \\
\text { expressed interest }\end{array}$ & $5-15$ & 10 & 39 & $10 \%$ & $143 \%$ \\
\hline 11 & $\begin{array}{l}\text { Number of angels that } \\
\text { expressed interest }\end{array}$ & $0-5$ & 3 & 28 & $40 \%$ & $221 \%$ \\
\hline 12 & $\begin{array}{l}\text { Number of angels that } \\
\text { expressed interest }\end{array}$ & $10-34$ & 20 & 94 & $19 \%$ & $166 \%$ \\
\hline 13 & $\begin{array}{l}\text { Average score given } \\
\text { by angels }\end{array}$ & $\begin{array}{l}80 \%- \\
100 \%\end{array}$ & $90 \%$ & 43 & $43 \%$ & $146 \%$ \\
\hline
\end{tabular}

Table presents the definitions of interest measures and funding cutoffs across groups. Column 2 presents measures of angel's interest for each group. If the level of interest for a venture falls in the range shown in column 3, a venture is classified as a part of the "border" sample. Column 4 shows the "cutoff" levels of interest and column 5 shows the "border" sample size. Column 6 shows the differences in average funding probability between ventures that are above and below the cutoff. Column 7 shows the differences in relative average funding probability between ventures that are above and below the cutoff. Relative funding probability is not reported when the probability to get funded for ventures below the cutoff is zero. 
Table 3 - Balance Test for the Cutoff Sample

\begin{tabular}{|c|c|c|c|c|c|}
\hline Venture's Characteristics & $\begin{array}{l}\text { Cutoff } \\
\text { Sample }\end{array}$ & $\begin{array}{c}\text { Above the cutoff } \\
\text { ventures }\end{array}$ & $\begin{array}{c}\text { Below the cutoff } \\
\text { ventures }\end{array}$ & $\begin{array}{l}\text { Above vs. } \\
\text { below }\end{array}$ & $\begin{array}{c}\text { Above vs. below - } \\
\text { demeaned difference }\end{array}$ \\
\hline Employment at the time of submission & $\begin{array}{l}10.25 \\
(16.18)\end{array}$ & $\begin{array}{c}11.53 \\
(15.74)\end{array}$ & $\begin{array}{l}9.293 \\
(16.46)\end{array}$ & $\begin{array}{l}2.235 \\
(1.537)\end{array}$ & $\begin{array}{l}2.350 \\
(1.489)\end{array}$ \\
\hline Observations & 452 & 193 & 259 & & \\
\hline Management team size & $\begin{array}{c}3.532 \\
(1.803)\end{array}$ & $\begin{array}{l}3.731 \\
(2.038)\end{array}$ & $\begin{array}{c}3.381 \\
(1.591)\end{array}$ & $\begin{array}{l}0.350 * * \\
(0.165)\end{array}$ & $\begin{array}{c}0.178 \\
(0.128)\end{array}$ \\
\hline Observations & 481 & 207 & 274 & & \\
\hline Financing sought (USD, thousands) & $\begin{array}{c}845.6 \\
(1,405)\end{array}$ & $\begin{array}{c}915.2 \\
(1,462)\end{array}$ & $\begin{array}{c}800.1 \\
(1,369)\end{array}$ & $\begin{array}{l}115.1 \\
(150.7)\end{array}$ & $\begin{array}{c}124.1 \\
(145.3)\end{array}$ \\
\hline Observations & 364 & 144 & 220 & & \\
\hline Patent count & $\begin{array}{l}1.23 \\
(6.56)\end{array}$ & $\begin{array}{c}1.27 \\
(5.75)\end{array}$ & $\begin{array}{c}1.20 \\
(7.07)\end{array}$ & $\begin{array}{c}0.07 \\
(6.47)\end{array}$ & $\begin{array}{c}0.02 \\
(4.58)\end{array}$ \\
\hline Observations & 578 & 235 & 343 & & \\
\hline Stage of Development & & & & & \\
\hline Initial idea & $\begin{array}{c}0.155 \\
(0.362)\end{array}$ & $\begin{array}{c}0.113 \\
(0.318)\end{array}$ & $\begin{array}{c}0.188 \\
(0.391)\end{array}$ & $\begin{array}{c}-0.0742 * * \\
(0.0339)\end{array}$ & $\begin{array}{l}-0.0652 \\
(0.0629)\end{array}$ \\
\hline Marketing and development & $\begin{array}{c}0.399 \\
(0.490)\end{array}$ & $\begin{array}{c}0.350 \\
(0.478)\end{array}$ & $\begin{array}{c}0.438 \\
(0.497)\end{array}$ & $\begin{array}{l}-0.0877 * \\
(0.0459)\end{array}$ & $\begin{array}{l}-0.0823 \\
(0.0638)\end{array}$ \\
\hline Revenue generating & $\begin{array}{c}0.447 \\
(0.498)\end{array}$ & $\begin{array}{c}0.537 \\
(0.500)\end{array}$ & $\begin{array}{c}0.375 \\
(0.485)\end{array}$ & $\begin{array}{c}0.162 * * * \\
(0.0462)\end{array}$ & $\begin{array}{c}0.148 \\
(0.0941)\end{array}$ \\
\hline Observations & 459 & 203 & 256 & & \\
\hline Industry & & & & & \\
\hline Biopharma, cleantech and healthcare & $\begin{array}{c}0.189 \\
(0.392)\end{array}$ & $\begin{array}{c}0.209 \\
(0.407)\end{array}$ & $\begin{array}{c}0.175 \\
(0.380)\end{array}$ & $\begin{array}{c}0.0336 \\
(0.0332)\end{array}$ & $\begin{array}{l}0.00393 \\
(0.0321)\end{array}$ \\
\hline Computers, electronics and measurement & $\begin{array}{c}0.201 \\
(0.401)\end{array}$ & $\begin{array}{c}0.238 \\
(0.427)\end{array}$ & $\begin{array}{c}0.175 \\
(0.380)\end{array}$ & $\begin{array}{l}0.0634 * \\
(0.0339)\end{array}$ & $\begin{array}{c}0.0706 \\
(0.0525)\end{array}$ \\
\hline Financial, educational and professional services & $\begin{array}{l}0.138 \\
(0.346)\end{array}$ & $\begin{array}{c}0.128 \\
(0.334)\end{array}$ & $\begin{array}{c}0.146 \\
(0.353)\end{array}$ & $\begin{array}{l}-0.0181 \\
(0.0293)\end{array}$ & $\begin{array}{l}-0.0264 \\
(0.0297)\end{array}$ \\
\hline Internet and e-commerce & $\begin{array}{c}0.142 \\
(0.349)\end{array}$ & $\begin{array}{c}0.115 \\
(0.320)\end{array}$ & $\begin{array}{c}0.160 \\
(0.367)\end{array}$ & $\begin{array}{c}-0.0455 \\
(0.0295)\end{array}$ & $\begin{array}{c}-0.0497 \\
(0.0379)\end{array}$ \\
\hline Technology, media and telecommunication & $\begin{array}{c}0.130 \\
(0.336)\end{array}$ & $\begin{array}{c}0.132 \\
(0.339)\end{array}$ & $\begin{array}{c}0.128 \\
(0.335)\end{array}$ & $\begin{array}{l}0.00364 \\
(0.0285)\end{array}$ & $\begin{array}{c}0.0104 \\
(0.0281)\end{array}$ \\
\hline Other & $\begin{array}{c}0.201 \\
(0.401)\end{array}$ & $\begin{array}{c}0.179 \\
(0.384)\end{array}$ & $\begin{array}{c}0.216 \\
(0.412)\end{array}$ & $\begin{array}{l}-0.0370 \\
(0.0339)\end{array}$ & $\begin{array}{l}-0.00890 \\
(0.0332)\end{array}$ \\
\hline Observations & 578 & 235 & 343 & & \\
\hline Total Observations & 578 & 235 & 343 & & \\
\hline
\end{tabular}


Table 4 - Outcomes for cutoff ventures

\begin{tabular}{|c|c|c|c|}
\hline Outcomes & $\begin{array}{l}\text { Above the } \\
\text { cutoff } \\
\text { ventures }\end{array}$ & $\begin{array}{l}\text { Below the } \\
\text { cutoff } \\
\text { ventures }\end{array}$ & $\begin{array}{c}\text { Above } \\
\text { vs. below }\end{array}$ \\
\hline \multicolumn{4}{|l|}{ Survival } \\
\hline$(0,1)$ Venture is in operation or underwent a successful exit & $\begin{array}{c}0.770 \\
(0.422)\end{array}$ & $\begin{array}{c}0.542 \\
(0.499)\end{array}$ & $\begin{array}{c}0.228 * * * \\
(0.0397)\end{array}$ \\
\hline$(0,1)$ Venture has a minimum of 1.5 years of operations since the financing event & $\begin{array}{c}0.787 \\
(0.410)\end{array}$ & $\begin{array}{c}0.636 \\
(0.482)\end{array}$ & $\begin{array}{c}0.152 * * * \\
(0.0385)\end{array}$ \\
\hline \multicolumn{4}{|l|}{ Success } \\
\hline$(0,1)$ Venture underwent IPO or acquisition & $\begin{array}{c}0.251 \\
(0.435) \\
\end{array}$ & $\begin{array}{l}0.0641 \\
(0.245) \\
\end{array}$ & $\begin{array}{c}0.187 * * * \\
(0.0284) \\
\end{array}$ \\
\hline \multicolumn{4}{|l|}{ Operations and growth } \\
\hline Employment count as of today & $\begin{array}{c}25.26 \\
(30.68)\end{array}$ & $\begin{array}{c}23.87 \\
(67.22)\end{array}$ & $\begin{array}{c}1.397 \\
(5.916)\end{array}$ \\
\hline Patent count after 1.5 years since the application for angel financing & $\begin{array}{c}1.923 \\
(6.937)\end{array}$ & $\begin{array}{c}1.936 \\
(9.583)\end{array}$ & $\begin{array}{l}-0.0125 \\
(0.729)\end{array}$ \\
\hline Patent count as of today & $\begin{array}{c}5.200 \\
(16.21)\end{array}$ & $\begin{array}{c}5.446 \\
(20.91)\end{array}$ & $\begin{array}{c}-0.246 \\
(1.621)\end{array}$ \\
\hline \multicolumn{4}{|l|}{ Founder's status } \\
\hline$(0,1)$ At least one of the founders is still with the venture & $\begin{array}{c}0.813 \\
(0.391)\end{array}$ & $\begin{array}{c}0.830 \\
(0.377)\end{array}$ & $\begin{array}{c}-0.0170 \\
(0.0413)\end{array}$ \\
\hline Founder is a CEO & $\begin{array}{c}0.624 \\
(0.486) \\
\end{array}$ & $\begin{array}{c}0.564 \\
(0.497) \\
\end{array}$ & $\begin{array}{c}0.0596 \\
(0.0586) \\
\end{array}$ \\
\hline \multicolumn{4}{|l|}{ Subsequent financing } \\
\hline$(0,1)$ Venture received any subsequent financing & $\begin{array}{c}0.417 \\
(0.494)\end{array}$ & $\begin{array}{c}0.204 \\
(0.404)\end{array}$ & $\begin{array}{c}0.213 * * * \\
(0.0375)\end{array}$ \\
\hline$(0,1)$ Venture received subsequent $\mathrm{VC}$ financing & $\begin{array}{c}0.230 \\
(0.422)\end{array}$ & $\begin{array}{c}0.105 \\
(0.307)\end{array}$ & $\begin{array}{c}0.125^{* * * *} \\
(0.0303)\end{array}$ \\
\hline Total subsequent financing raised (USD, millions) & $\begin{array}{c}14.09 \\
(50.91)\end{array}$ & $\begin{array}{c}10.94 \\
(17.15)\end{array}$ & $\begin{array}{c}3.152 \\
(7.905)\end{array}$ \\
\hline
\end{tabular}

Observations

235

343

Table presents the outcome information for 578 ventures below and above the funding cutoff. Columns1 and 2 present information for ventures below and above the cutoff separately. Column 3 tests for the equality of the means between ventures below and above the funding cutoff and presents the differences between the means. $* * *$ and $* * *$ denote statistical significance at $10 \%, 5 \%$ and $1 \%$ levels respectively. 
Table 5 - Venture's outcomes across countries

\begin{tabular}{|c|c|c|c|c|c|c|c|}
\hline \multirow[b]{2}{*}{$\overline{\text { Outcomes }}$} & \multicolumn{7}{|c|}{ Ventures in countries } \\
\hline & $\begin{array}{l}\text { Cutoff } \\
\text { sample }\end{array}$ & $\begin{array}{c}\text { with } \\
\text { above the } \\
\text { median } \\
\text { VC to } \\
\text { GDP } \\
\text { Ratio }\end{array}$ & $\begin{array}{c}\text { with } \\
\text { below the } \\
\text { median } \\
\text { VC to } \\
\text { GDP } \\
\text { Ratio }\end{array}$ & $\begin{array}{c}\text { Above } \\
\text { vs. below }\end{array}$ & $\begin{array}{c}\text { with } \\
\text { above the } \\
\text { median } \\
\text { number } \\
\text { of steps to } \\
\text { open } \\
\text { business }\end{array}$ & $\begin{array}{c}\text { with } \\
\text { below the } \\
\text { median } \\
\text { number } \\
\text { of steps to } \\
\text { open } \\
\text { business }\end{array}$ & $\begin{array}{c}\text { Above } \\
\text { vs. below }\end{array}$ \\
\hline \multicolumn{8}{|l|}{ Survival } \\
\hline \multirow[t]{2}{*}{$\begin{array}{l}(0,1) \text { Venture is in operation or underwent a successful } \\
\text { exit }\end{array}$} & 0.635 & 0.650 & 0.625 & 0.025 & 0.531 & 0.722 & $-0.191 * * *$ \\
\hline & $(0.482)$ & $(0.478)$ & $(0.485)$ & $(0.041)$ & $(0.500)$ & $(0.449)$ & $(0.040)$ \\
\hline \multirow{2}{*}{$\begin{array}{l}(0,1) \text { Venture has a minimum of } 1.5 \text { years of operations } \\
\text { since the financing event }\end{array}$} & 0.697 & 0.668 & 0.716 & -0.048 & 0.649 & 0.737 & $-0.088 * *$ \\
\hline & $(0.460)$ & $(0.472)$ & $(0.452)$ & $(0.039)$ & $(0.478)$ & $(0.441)$ & $(0.038)$ \\
\hline \multicolumn{8}{|l|}{ Success } \\
\hline$(0,1)$ Venture underwent IPO or acquisition & $\begin{array}{c}0.140 \\
(0.347) \\
\end{array}$ & $\begin{array}{c}0.243 \\
(0.430) \\
\end{array}$ & $\begin{array}{c}0.074 \\
(0.262) \\
\end{array}$ & $\begin{array}{c}0.169 * * * \\
(0.029)\end{array}$ & $\begin{array}{c}0.080 \\
(0.272) \\
\end{array}$ & $\begin{array}{c}0.190 \\
(0.393) \\
\end{array}$ & $\begin{array}{c}-0.110 * * * \\
(0.029)\end{array}$ \\
\hline \multicolumn{8}{|l|}{ Operations and growth } \\
\hline Employment count as of today & $\begin{array}{c}24.564 \\
(52.170)\end{array}$ & $\begin{array}{c}36.936 \\
(78.225)\end{array}$ & $\begin{array}{c}17.827 \\
(27.632)\end{array}$ & $\begin{array}{c}19.110 * * * \\
(6.096)\end{array}$ & $\begin{array}{c}19.896 \\
(32.536)\end{array}$ & $\begin{array}{c}27.684 \\
(61.812)\end{array}$ & $\begin{array}{l}-7.788 \\
(6.021)\end{array}$ \\
\hline \multirow[t]{2}{*}{$\begin{array}{l}\text { Patent count after } 1.5 \text { years since the application for angel } \\
\text { financing }\end{array}$} & 1.931 & 2.562 & 1.526 & 1.036 & 0.969 & 2.728 & $-1.758 * *$ \\
\hline & $(8.599)$ & $(7.886)$ & $(9.015)$ & $(0.732)$ & $(8.926)$ & $(8.248)$ & $(0.715)$ \\
\hline Patent count as of today & $\begin{array}{c}5.346 \\
(19.121)\end{array}$ & $\begin{array}{c}9.606 \\
(24.380)\end{array}$ & $\begin{array}{c}2.611 \\
(14.170)\end{array}$ & $\begin{array}{c}6.995^{* * *} \\
(1.605)\end{array}$ & $\begin{array}{c}1.504 \\
(14.114)\end{array}$ & $\begin{array}{c}8.532 \\
(21.959)\end{array}$ & $\begin{array}{c}-7.028 * * * \\
(1.572)\end{array}$ \\
\hline Observations & 578 & 226 & 352 & & 262 & 316 & \\
\hline
\end{tabular}

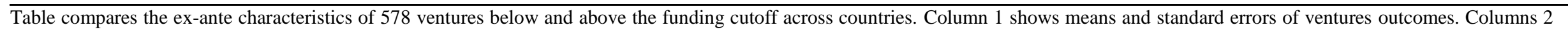

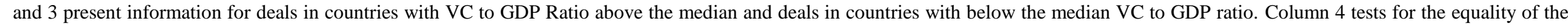

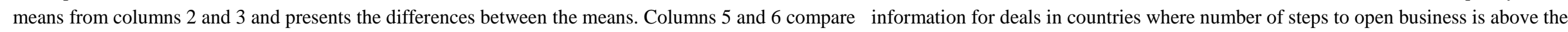

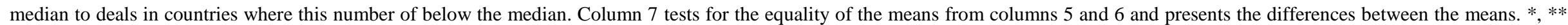
and $* * *$ denote statistical significance at $10 \%, 5 \%$ and $1 \%$ levels respectively. 
Table 5 - Venture's outcomes across countries (continued)

\begin{tabular}{|c|c|c|c|c|c|c|c|}
\hline \multirow[b]{2}{*}{ Outcomes } & \multicolumn{7}{|c|}{ Ventures in countries } \\
\hline & $\begin{array}{l}\text { Cutoff } \\
\text { sample }\end{array}$ & $\begin{array}{c}\text { with } \\
\text { above the } \\
\text { median } \\
\text { VC to } \\
\text { GDP } \\
\text { Ratio }\end{array}$ & $\begin{array}{c}\text { with } \\
\text { below the } \\
\text { median } \\
\text { VC to } \\
\text { GDP } \\
\text { Ratio }\end{array}$ & $\begin{array}{c}\text { Above } \\
\text { vs. below }\end{array}$ & $\begin{array}{c}\text { with } \\
\text { above the } \\
\text { median } \\
\text { number } \\
\text { of steps to } \\
\text { open } \\
\text { business }\end{array}$ & $\begin{array}{c}\text { with } \\
\text { below the } \\
\text { median } \\
\text { number } \\
\text { of steps to } \\
\text { open } \\
\text { business }\end{array}$ & $\begin{array}{c}\text { Above } \\
\text { vs. below } \\
\end{array}$ \\
\hline \multicolumn{8}{|l|}{ Founder's status } \\
\hline$(0,1)$ At least one of the founders is still with the venture & $\begin{array}{c}0.822 \\
(0.383)\end{array}$ & $\begin{array}{c}0.783 \\
(0.414)\end{array}$ & $\begin{array}{c}0.845 \\
(0.362)\end{array}$ & $\begin{array}{l}-0.063 \\
(0.042)\end{array}$ & $\begin{array}{c}0.894 \\
(0.309)\end{array}$ & $\begin{array}{c}0.774 \\
(0.419)\end{array}$ & $\begin{array}{c}0.120 * * * \\
(0.041)\end{array}$ \\
\hline Founder is a CEO & $\begin{array}{c}0.590 \\
(0.493) \\
\end{array}$ & $\begin{array}{c}0.545 \\
(0.500) \\
\end{array}$ & $\begin{array}{c}0.615 \\
(0.488) \\
\end{array}$ & $\begin{array}{c}-0.070 \\
(0.061) \\
\end{array}$ & $\begin{array}{c}0.648 \\
(0.480) \\
\end{array}$ & $\begin{array}{c}0.546 \\
(0.499) \\
\end{array}$ & $\begin{array}{l}0.102 * \\
(0.058) \\
\end{array}$ \\
\hline \multicolumn{8}{|l|}{ Subsequent financing } \\
\hline$(0,1)$ Venture received any subsequent financing & $\begin{array}{c}0.291 \\
(0.454)\end{array}$ & $\begin{array}{c}0.412 \\
(0.493)\end{array}$ & $\begin{array}{c}0.213 \\
(0.410)\end{array}$ & $\begin{array}{c}0.198 * * * \\
(0.038)\end{array}$ & $\begin{array}{c}0.122 \\
(0.328)\end{array}$ & $\begin{array}{c}0.430 \\
(0.496)\end{array}$ & $\begin{array}{c}-0.308 * * * \\
(0.036)\end{array}$ \\
\hline$(0,1)$ Venture received subsequent $\mathrm{VC}$ financing & $\begin{array}{c}0.156 \\
(0.363)\end{array}$ & $\begin{array}{c}0.230 \\
(0.422)\end{array}$ & $\begin{array}{c}0.108 \\
(0.311)\end{array}$ & $\begin{array}{c}0.122 * * * \\
(0.031)\end{array}$ & $\begin{array}{c}0.061 \\
(0.240)\end{array}$ & $\begin{array}{c}0.234 \\
(0.424)\end{array}$ & $\begin{array}{c}-0.173^{* * * *} \\
(0.029)\end{array}$ \\
\hline Total subsequent financing raised (USD, millions) & $\begin{array}{c}12.767 \\
(40.204)\end{array}$ & $\begin{array}{c}20.145 \\
(52.543)\end{array}$ & $\begin{array}{c}3.348 \\
(4.692)\end{array}$ & $\begin{array}{c}16.797 * * \\
(7.696)\end{array}$ & $\begin{array}{c}3.356 \\
(5.031)\end{array}$ & $\begin{array}{c}15.202 \\
(44.768)\end{array}$ & $\begin{array}{l}-11.847 \\
(9.593)\end{array}$ \\
\hline
\end{tabular}

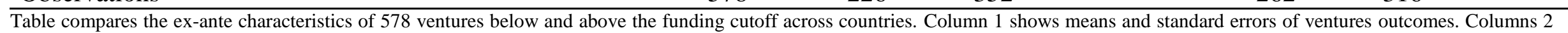

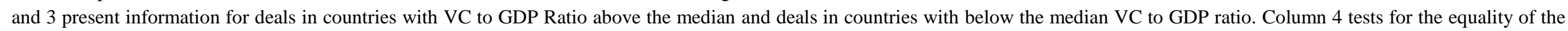

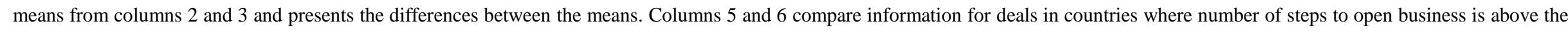

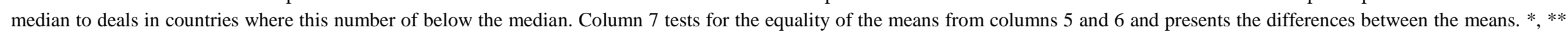
and $* * *$ denote statistical significance at $10 \%, 5 \%$ and $1 \%$ levels respectively. 
Table 6 - Discontinuity and funding status

\begin{tabular}{|c|c|c|c|c|c|}
\hline & \multicolumn{5}{|c|}{$(0,1)$ Venture received funding from angel group } \\
\hline & (1) & (2) & (3) & (4) & (5) \\
\hline$(0,1)$ Venture is above the funding cutoff & $\begin{array}{c}0.303 * * * \\
(0.0382)\end{array}$ & $\begin{array}{c}0.269 * * * \\
(0.0367)\end{array}$ & $\begin{array}{c}0.252 * * * \\
(0.0375)\end{array}$ & $\begin{array}{c}0.255^{* * *} * \\
(0.0376)\end{array}$ & $\begin{array}{c}0.183 * * * \\
(0.0466)\end{array}$ \\
\hline Observations & 578 & 578 & 568 & 568 & 307 \\
\hline R-squared & 0.109 & 0.251 & 0.288 & 0.293 & 0.368 \\
\hline Angel group FE & No & Yes & Yes & Yes & Yes \\
\hline Year FE & No & No & Yes & Yes & Yes \\
\hline Industry FE & No & No & No & Yes & Yes \\
\hline Venture level controls & No & No & No & No & Yes \\
\hline
\end{tabular}

Table presents results of linear regressions of venture's funding status on a dummy variable that equals one if the venture is above the funding cutoff. Column 1 presents the basic specification and the following columns add control variables. Column 2 adds angel group fixed effects. Column 3 adds year fixed effects. Column 4 adds industry fixed effects and column 5 adds venture-level controls. *, ** and *** denote statistical significance at $10 \%, 5 \%$ and $1 \%$ levels respectively. Robust standard errors are reported. 
Table 7 - Outcomes and funding status - Panel A

\begin{tabular}{|c|c|c|c|c|c|c|c|c|}
\hline & \multirow{2}{*}{\multicolumn{2}{|c|}{$\begin{array}{c}(1) \\
(0,1) \text { Venture is in } \\
\text { operation or underwent } \\
\text { a successful exit }\end{array}$}} & \multirow{2}{*}{\multicolumn{2}{|c|}{$\begin{array}{l}(3) \\
(0,1) \text { Venture has a } \\
\text { minimum of } 1.5 \text { years } \\
\text { of operations since the } \\
\text { financing event }\end{array}$}} & $(5)$ & (6) & $(7)$ & $(8)$ \\
\hline & & & & & \multicolumn{2}{|c|}{$\begin{array}{l}(0,1) \text { Venture } \\
\text { underwent IPO or } \\
\text { acquisition }\end{array}$} & \multicolumn{2}{|c|}{ Log(Employment) } \\
\hline$(0,1)$ Venture received funding from angel group & $\begin{array}{c}0.228 * * * \\
(0.043)\end{array}$ & $\begin{array}{c}0.168 * * \\
(0.065)\end{array}$ & $\begin{array}{c}0.139 * * * \\
(0.037)\end{array}$ & $\begin{array}{c}0.017 \\
(0.045)\end{array}$ & $\begin{array}{c}0.173 * * * \\
(0.037)\end{array}$ & $\begin{array}{c}0.008 \\
(0.029)\end{array}$ & $\begin{array}{c}0.486 * * * \\
(0.134)\end{array}$ & $\begin{array}{c}0.402 * * * \\
(0.156)\end{array}$ \\
\hline Observations & 568 & 307 & 568 & 307 & 568 & 307 & 307 & 185 \\
\hline R-squared & 0.220 & 0.258 & 0.273 & 0.367 & 0.254 & 0.062 & 0.322 & 0.497 \\
\hline Angel group FE & Yes & Yes & Yes & Yes & Yes & Yes & Yes & Yes \\
\hline Year FE & Yes & Yes & Yes & Yes & Yes & Yes & Yes & Yes \\
\hline Industry FE & Yes & Yes & Yes & Yes & Yes & Yes & Yes & Yes \\
\hline Venture level controls & No & Yes & No & Yes & No & Yes & No & Yes \\
\hline
\end{tabular}

Table 7 - Outcomes and funding status - Panel B

\begin{tabular}{|c|c|c|c|c|c|c|c|c|c|c|}
\hline \multirow{4}{*}{$\begin{array}{l}\text { (0,1)Venture received } \\
\text { funding from angel group }\end{array}$} & \multirow{2}{*}{\multicolumn{2}{|c|}{$\begin{array}{l}(1) \quad(2) \\
\begin{array}{c}\text { Patent count as of } \\
\text { today }\end{array}\end{array}$}} & \multirow{2}{*}{\multicolumn{2}{|c|}{$\begin{array}{c}\text { (3) } \\
(0,1) \text { At least one of } \\
\text { the founders is still } \\
\text { with the venture }\end{array}$}} & \multirow{2}{*}{\multicolumn{2}{|c|}{$\begin{array}{c}(5) \\
(0,1) \text { Venture received } \\
\text { any subsequent financing }\end{array}$}} & \multirow{2}{*}{\multicolumn{2}{|c|}{$\begin{array}{c}(7) \quad(8) \\
(0,1) \text { Venture received } \\
\text { subsequent VC } \\
\text { financing } \\
\end{array}$}} & \multirow{2}{*}{\multicolumn{2}{|c|}{$\begin{array}{l}(9) \quad(10) \\
\text { Total subsequent } \\
\text { financing raised } \\
\text { (USD, millions) }\end{array}$}} \\
\hline & & & & & & & & & & \\
\hline & 1.824 & 1.736 & -0.014 & 0.095 & $0.157 * * *$ & $0.234 * * *$ & 0.052 & $0.103 *$ & 7.718 & -0.999 \\
\hline & $(2.078)$ & $(1.072)$ & $(0.053)$ & $(0.072)$ & $(0.049)$ & $(0.073)$ & $(0.039)$ & $(0.054)$ & $(7.165)$ & $(6.703)$ \\
\hline Observations & 568 & 307 & 343 & 196 & 568 & 307 & 568 & 307 & 107 & 45 \\
\hline R-squared & 0.118 & 0.871 & 0.164 & 0.144 & 0.197 & 0.269 & 0.178 & 0.311 & 0.239 & 0.987 \\
\hline Angel group FE & Yes & Yes & Yes & Yes & Yes & Yes & Yes & Yes & Yes & Yes \\
\hline Year FE & Yes & Yes & Yes & Yes & Yes & Yes & Yes & Yes & Yes & Yes \\
\hline Industry FE & Yes & Yes & Yes & Yes & Yes & Yes & Yes & Yes & Yes & Yes \\
\hline Venture level controls & No & Yes & No & Yes & No & Yes & No & Yes & No & Yes \\
\hline
\end{tabular}

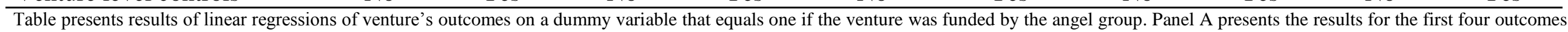

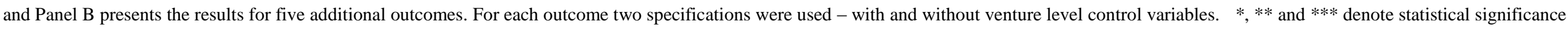
at $10 \%, 5 \%$ and $1 \%$ levels respectively. Robust standard errors are reported. 
Table 8 - Outcomes and discontinuity - Panel A

$\begin{array}{llll}(1) & \text { (2) (3) }\end{array}$

$(0,1)$ Venture is in $\quad(0,1)$ Venture has a

operation or underwent a minimum of 1.5 years

successful exit of operations since the

(5)

(6)

$(0,1)$ Venture underwent

(7)

(8)

IPO or acquisition

financing event

$(0,1)$ Venture is above the funding cutoff

\begin{tabular}{l} 
Observations \\
R-squared \\
Angel group FE \\
Year FE \\
Industry FE \\
Venture level controls \\
\hline
\end{tabular}

Observations

R-squared

Year FE

Venture level controls

$\begin{array}{cccccccc}0.181 * * * & 0.194 * * * & 0.105 * * * & 0.069 & 0.161 * * * & 0.087 * * * & 0.392 * * * & 0.430 * * * \\ (0.040) & (0.054) & (0.036) & (0.045) & (0.031) & (0.030) & (0.116) & (0.132)\end{array}$

$\begin{array}{cc}568 & 307 \\ 0.215 & 0.279 \\ \text { Yes } & \text { Yes } \\ \text { Yes } & \text { Yes } \\ \text { Yes } & \text { Yes } \\ \text { No } & \text { Yes }\end{array}$

Table 8 - Outcomes and discontinuity - Panel B

\begin{tabular}{|c|c|c|c|c|c|c|c|c|c|c|}
\hline \multirow{4}{*}{$\begin{array}{l}(0,1) \text { Venture is above the } \\
\text { funding cutoff }\end{array}$} & $(1)$ & (2) & (3) & (4) & $(5)$ & (6) & (7) & $(8)$ & (9) & $(10)$ \\
\hline & \multicolumn{2}{|c|}{$\begin{array}{l}\text { Patent count as of } \\
\text { today }\end{array}$} & \multicolumn{2}{|c|}{$\begin{array}{c}(0,1) \text { At least one of } \\
\text { the founders is still } \\
\text { with the venture }\end{array}$} & \multicolumn{2}{|c|}{$\begin{array}{c}(0,1) \text { Venture received } \\
\text { any subsequent financing }\end{array}$} & \multicolumn{2}{|c|}{$\begin{array}{l}(0,1) \text { Venture received } \\
\text { subsequent VC } \\
\text { financing }\end{array}$} & \multicolumn{2}{|c|}{$\begin{array}{l}\text { Total subsequent } \\
\text { financing raised } \\
\text { (USD, millions) } \\
\end{array}$} \\
\hline & -1.564 & -0.237 & 0.014 & 0.001 & $0.163 * * *$ & $0.213 * * *$ & $0.089 * * *$ & $0.093 * *$ & 4.913 & 1.719 \\
\hline & $(1.595)$ & $(0.793)$ & $(0.043)$ & $(0.057)$ & $(0.039)$ & $(0.050)$ & $(0.032)$ & $(0.038)$ & $(7.680)$ & (4.294) \\
\hline Observations & 568 & 307 & 343 & 196 & 568 & 307 & 568 & 307 & 107 & 45 \\
\hline R-squared & 0.118 & 0.869 & 0.164 & 0.135 & 0.206 & 0.287 & 0.187 & 0.316 & 0.236 & 0.987 \\
\hline Angel group FE & Yes & Yes & Yes & Yes & Yes & Yes & Yes & Yes & Yes & Yes \\
\hline Year FE & Yes & Yes & Yes & Yes & Yes & Yes & Yes & Yes & Yes & Yes \\
\hline Industry FE & Yes & Yes & Yes & Yes & Yes & Yes & Yes & Yes & Yes & Yes \\
\hline Venture level controls & No & Yes & No & Yes & No & Yes & No & Yes & No & Yes \\
\hline
\end{tabular}

Table presents results of linear regressions of venture's outcomes on a dummy variable that equals one if the venture is above the funding cutoff. Panel A presents the results for the first four outcomes and Panel B presetns the results for five additional outcomes. For each outcome two specifications were used - with and without venture level control variables. * ** and $* * *$ denote statistical significance at $10 \%, 5 \%$ and $1 \%$ levels respectively. Robust standard errors are reported. 
Table 9 - Angel financing effect across countries - Steps to open business

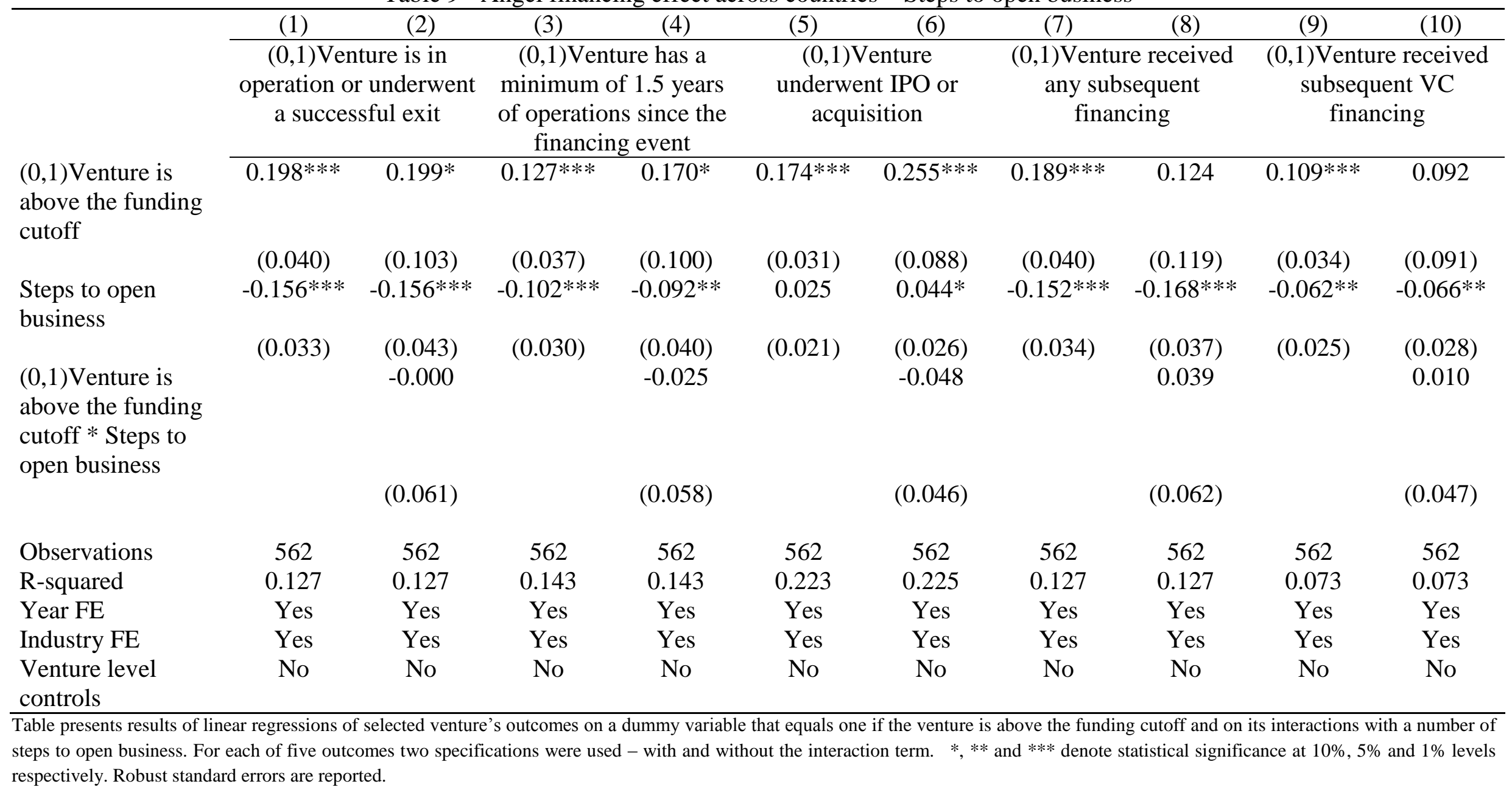


Table 9 - Angel financing effect across countries - VC to GDP Ratio

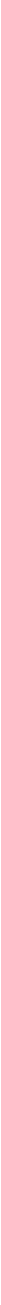


Table 10 - Firm's characteristics across countries - Panel A - Full Sample

\begin{tabular}{|c|c|c|c|c|c|c|}
\hline \multirow[b]{2}{*}{ Venture's characteristics } & \multicolumn{6}{|c|}{ Ventures in countries } \\
\hline & $\begin{array}{l}\text { with above the } \\
\text { median number } \\
\text { of steps to open } \\
\text { business }\end{array}$ & $\begin{array}{l}\text { with below the } \\
\text { median number } \\
\text { of steps to open } \\
\text { business }\end{array}$ & $\begin{array}{c}\text { Above } \\
\text { vs. below }\end{array}$ & $\begin{array}{l}\text { with above the } \\
\text { median VC to } \\
\text { GDP Ratio }\end{array}$ & $\begin{array}{l}\text { with below the } \\
\text { median VC to } \\
\text { GDP Ratio }\end{array}$ & $\begin{array}{c}\text { Above } \\
\text { vs. below }\end{array}$ \\
\hline Employment at the time of submission & $\begin{array}{l}11.472 \\
(22.051)\end{array}$ & $\begin{array}{c}8.671 \\
(22.164)\end{array}$ & $\begin{array}{l}2.802 * * \\
(1.202)\end{array}$ & $\begin{array}{c}10.229 \\
(26.217)\end{array}$ & $\begin{array}{c}9.791 \\
(19.760)\end{array}$ & $\begin{array}{c}0.439 \\
(1.267)\end{array}$ \\
\hline Management Team Size & $\begin{array}{c}3.156 \\
(1.481)\end{array}$ & $\begin{array}{c}3.601 \\
(1.993)\end{array}$ & $\begin{array}{c}-0.445 * * * \\
(0.093)\end{array}$ & $\begin{array}{c}3.749 \\
(2.339)\end{array}$ & $\begin{array}{c}3.218 \\
(1.410)\end{array}$ & $\begin{array}{c}0.531 * * * \\
(0.099)\end{array}$ \\
\hline Stage of development & & & & & & \\
\hline Initial idea & $\begin{array}{c}0.098 \\
(0.298)\end{array}$ & $\begin{array}{c}0.260 \\
(0.439)\end{array}$ & $\begin{array}{c}-0.162 * * * \\
(0.020)\end{array}$ & $\begin{array}{c}0.255 \\
(0.436)\end{array}$ & $\begin{array}{c}0.152 \\
(0.359)\end{array}$ & $\begin{array}{c}0.103 * * * \\
(0.022)\end{array}$ \\
\hline Marketing and development & $\begin{array}{c}0.488 \\
(0.500)\end{array}$ & $\begin{array}{c}0.365 \\
(0.482)\end{array}$ & $\begin{array}{c}0.123 * * * \\
(0.026)\end{array}$ & $\begin{array}{c}0.350 \\
(0.477)\end{array}$ & $\begin{array}{c}0.457 \\
(0.498)\end{array}$ & $\begin{array}{c}-0.107 * * * \\
(0.028)\end{array}$ \\
\hline Revenue generating & $\begin{array}{c}0.413 \\
(0.493)\end{array}$ & $\begin{array}{c}0.375 \\
(0.484)\end{array}$ & $\begin{array}{c}0.039 \\
(0.026)\end{array}$ & $\begin{array}{c}0.395 \\
(0.489)\end{array}$ & $\begin{array}{c}0.391 \\
(0.488)\end{array}$ & $\begin{array}{c}0.004 \\
(0.028)\end{array}$ \\
\hline $\begin{array}{l}\text { Computers, electronics and } \\
\text { measurement }\end{array}$ & $\begin{array}{c}0.086 \\
(0.280)\end{array}$ & $\begin{array}{l}0.194 \\
(0.396)\end{array}$ & $\begin{array}{c}-0.109 * * * \\
(0.017)\end{array}$ & $\begin{array}{c}0.195 \\
(0.396)\end{array}$ & $\begin{array}{l}0.118 \\
(0.323)\end{array}$ & $\begin{array}{c}0.077 * * * \\
(0.018)\end{array}$ \\
\hline $\begin{array}{l}\text { Financial, educational and professional } \\
\text { services }\end{array}$ & $\begin{array}{c}0.081 \\
(0.274)\end{array}$ & $\begin{array}{l}0.103 \\
(0.304)\end{array}$ & $\begin{array}{l}-0.022 \\
(0.014)\end{array}$ & $\begin{array}{l}0.128 \\
(0.335)\end{array}$ & $\begin{array}{c}0.073 \\
(0.259)\end{array}$ & $\begin{array}{c}0.056 * * * \\
(0.015)\end{array}$ \\
\hline Internet and e-commerce & $\begin{array}{c}0.293 \\
(0.455)\end{array}$ & $\begin{array}{c}0.098 \\
(0.297)\end{array}$ & $\begin{array}{l}0.195 * * * \\
(0.019)\end{array}$ & $\begin{array}{c}0.092 \\
(0.289)\end{array}$ & $\begin{array}{c}0.238 \\
(0.426)\end{array}$ & $\begin{array}{l}-0.146 * * * \\
(0.019)\end{array}$ \\
\hline Other & $\begin{array}{c}0.327 \\
(0.470)\end{array}$ & $\begin{array}{c}0.344 \\
(0.475)\end{array}$ & $\begin{array}{l}-0.017 \\
(0.023)\end{array}$ & $\begin{array}{c}0.353 \\
(0.478)\end{array}$ & $\begin{array}{c}0.327 \\
(0.469)\end{array}$ & $\begin{array}{c}0.027 \\
(0.024)\end{array}$ \\
\hline $\begin{array}{l}\text { Technology, media and } \\
\text { telecommunication }\end{array}$ & $\begin{array}{l}0.119 \\
(0.324)\end{array}$ & $\begin{array}{c}0.083 \\
(0.276)\end{array}$ & $\begin{array}{l}0.036 * * \\
(0.015)\end{array}$ & $\begin{array}{c}0.073 \\
(0.260)\end{array}$ & $\begin{array}{l}0.114 \\
(0.318)\end{array}$ & $\begin{array}{c}-0.041 * * * \\
(0.015)\end{array}$ \\
\hline Observations & 724 & 958 & & 648 & 1,034 & \\
\hline
\end{tabular}

Panel A compares the ex-ante characteristics of 1,682 ventures across countries. Columns 1 and 2 compare information for deals in countries where number of steps to open business is above the median to deals in countries where this number of below the median. Column 3 tests for the equality of the means from columns 1 and 2 and presents the differences between the means Columns 4 and 5 present information for deals in countries with VC to GDP Ratio above the median and deals in countries with below the median VC to GDP ratio. Column 6 tests for the equality of the means from columns 4 and 5 and presents the differences between the means. *,* and *** denote statistical significance at $10 \%, 5 \%$ and $1 \%$ levels respectively. 
Table 10 - Firm's characteristics across countries - Panel B - Border Sample

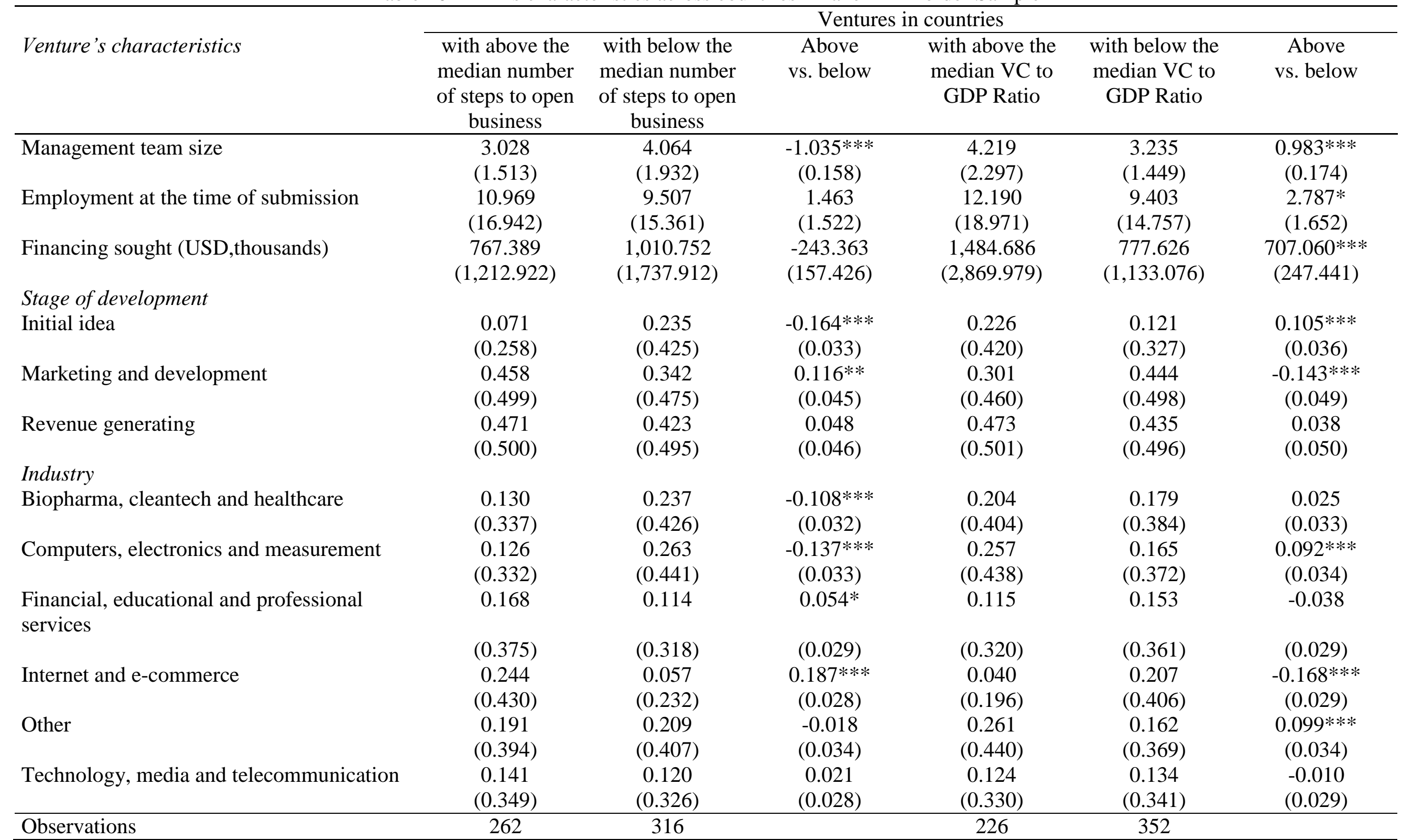

Panel B compares the ex-ante characteristics of the 578 ventures in the "border" sample across countries. Columns 1 and 2 present information for deals in countries where number of steps to open business is above the median vs deals in countries where this number of below the median. Column 3 tests for the equality of the means from columns 1 and 2 and presents the differences between the means. Columns 4 and 5 present information for deals in countries with VC to GDP Ratio above the median and deals in countries with below the median VC to GDP ratio. Column 6 tests for the equality of the means from columns 4 and 5 and presents the differences between the means. $*, * *$ and $* * *$ denote statistical significance at $10 \%, 5 \%$ and $1 \%$ levels respectively. 
Table 11 - Deal composition across countries - Steps to open business - Panel A

\begin{tabular}{|c|c|c|c|c|c|c|}
\hline \multirow[b]{3}{*}{$\begin{array}{l}(0,1) \text { Venture received funding from } \\
\text { angel group }\end{array}$} & $(1)$ & (2) & (3) & (4) & $(5)$ & (6) \\
\hline & \multicolumn{2}{|c|}{ Employment } & \multicolumn{2}{|c|}{ Management Team Size } & \multicolumn{2}{|c|}{$\begin{array}{l}\text { Financing sought (USD, } \\
\text { thousands) }\end{array}$} \\
\hline & $\begin{array}{l}5.231 * * \\
(2.362)\end{array}$ & $\begin{array}{l}-0.107 \\
(3.250)\end{array}$ & $\begin{array}{c}0.365 * * * \\
(0.124)\end{array}$ & $\begin{array}{c}1.297 * * * \\
(0.355)\end{array}$ & $\begin{array}{l}107.023 \\
(241.683)\end{array}$ & $\begin{array}{l}-64.548 \\
(317.565)\end{array}$ \\
\hline \multirow{3}{*}{$\begin{array}{l}\text { Steps to open business } \\
(0,1) \text { Venture received funding from } \\
\text { angel group * Steps to open business }\end{array}$} & $\begin{array}{c}3.226 * * * \\
(0.975)\end{array}$ & $\begin{array}{c}2.728 * * * \\
(1.028)\end{array}$ & $\begin{array}{l}-0.288 * * * \\
(0.068)\end{array}$ & $\begin{array}{l}-0.196 * * * \\
(0.071)\end{array}$ & $\begin{array}{c}31.688 \\
(80.962)\end{array}$ & $\begin{array}{c}13.657 \\
(84.548)\end{array}$ \\
\hline & & 3.319 & & $-0.571 * * *$ & & 103.274 \\
\hline & & $(2.421)$ & & $(0.202)$ & & $(182.810)$ \\
\hline Observations & 1,311 & 1,311 & 1,386 & 1,386 & 1,390 & 1,390 \\
\hline R-squared & 0.034 & 0.035 & 0.226 & 0.231 & 0.018 & 0.018 \\
\hline Year FE & Yes & Yes & Yes & Yes & Yes & Yes \\
\hline Industry FE & Yes & Yes & Yes & Yes & Yes & Yes \\
\hline
\end{tabular}

Table 11 - Deal composition across countries - Steps to open business - Panel B

\begin{tabular}{|c|c|c|c|c|c|c|}
\hline & $(1)$ & $(2)$ & (3) & $(4)$ & $(5)$ & $(6)$ \\
\hline & \multicolumn{6}{|c|}{ Stage of development } \\
\hline & \multicolumn{2}{|c|}{ Initial idea } & \multicolumn{2}{|c|}{ Marketing and development } & \multicolumn{2}{|c|}{ Revenue generating } \\
\hline \multirow{2}{*}{$\begin{array}{l}(0,1) \text { Venture received funding from } \\
\text { angel group }\end{array}$} & $-0.107 * * *$ & $-0.155^{* *}$ & -0.008 & 0.048 & $0.114 * * *$ & 0.107 \\
\hline & $(0.025)$ & $(0.067)$ & $(0.036)$ & $(0.105)$ & $(0.036)$ & $(0.107)$ \\
\hline \multirow[t]{2}{*}{ Steps to open business } & $-0.071 * * *$ & $-0.075 * * *$ & $0.058 * *$ & $0.063 * *$ & 0.012 & 0.012 \\
\hline & $(0.020)$ & $(0.021)$ & $(0.025)$ & $(0.027)$ & $(0.023)$ & $(0.025)$ \\
\hline \multirow{2}{*}{$\begin{array}{l}(0,1) \text { Venture received funding from } \\
\text { angel group *Steps to open business }\end{array}$} & & 0.030 & & -0.034 & & 0.005 \\
\hline & & $(0.037)$ & & $(0.062)$ & & $(0.063)$ \\
\hline Observations & 1,356 & 1,356 & 1,356 & 1,356 & 1,356 & 1,356 \\
\hline R-squared & 0.083 & 0.083 & 0.028 & 0.028 & 0.059 & 0.059 \\
\hline Year FE & Yes & Yes & Yes & Yes & Yes & Yes \\
\hline Industry FE & Yes & Yes & Yes & Yes & Yes & Yes \\
\hline
\end{tabular}

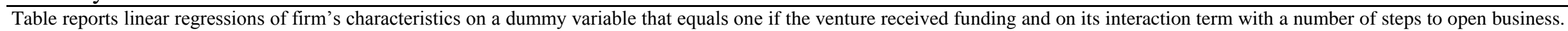

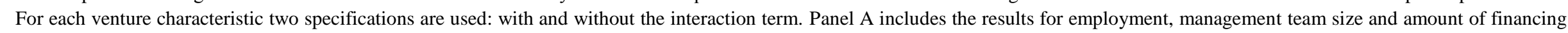

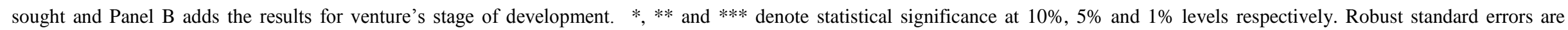
reported. 
Table 11 - Deal composition across countries - VC to GDP Ratio - Panel C

\begin{tabular}{|c|c|c|c|c|c|c|}
\hline \multirow[b]{3}{*}{$\begin{array}{l}(0,1) \text { Venture received funding from } \\
\text { angel group }\end{array}$} & (1) & (2) & (3) & (4) & $(5)$ & (6) \\
\hline & \multicolumn{2}{|c|}{ Employment } & \multicolumn{2}{|c|}{ Management Team Size } & \multicolumn{2}{|c|}{$\begin{array}{l}\text { Financing sought (USD, } \\
\text { thousands) }\end{array}$} \\
\hline & $\begin{array}{l}4.860 * * \\
(2.340)\end{array}$ & $\begin{array}{l}7.400 * * \\
(3.460)\end{array}$ & $\begin{array}{c}0.391 * * * \\
(0.112)\end{array}$ & $\begin{array}{l}0.239 \\
(0.159)\end{array}$ & $\begin{array}{c}120.278 \\
(239.927)\end{array}$ & $\begin{array}{l}417.539 \\
(305.485)\end{array}$ \\
\hline $\begin{array}{l}\text { VC to GDP Ratio } \\
(0,1) \text { Venture received funding from }\end{array}$ & $\begin{array}{c}3,161.679 * * * \\
(1,069.719)\end{array}$ & $\begin{array}{c}3,885.230 * * * \\
(1,150.348) \\
-3,334.140\end{array}$ & $\begin{array}{l}1,703.820 * * * \\
\quad(114.683)\end{array}$ & $\begin{array}{c}1,658.818 * * * \\
(115.683) \\
207.735\end{array}$ & $\begin{array}{r}484,127.729 * * \\
(188,758.046)\end{array}$ & $\begin{array}{c}576,246.490 * * * \\
(215,396.596) \\
-406,564.684 *\end{array}$ \\
\hline & & $(2,061.899)$ & & (192.589) & & $(220,837.326)$ \\
\hline Observations & 1,311 & 1,311 & 1,386 & 1,386 & 1,390 & 1,390 \\
\hline R-squared & 0.030 & 0.032 & 0.334 & 0.335 & 0.021 & 0.023 \\
\hline Year FE & Yes & Yes & Yes & Yes & Yes & Yes \\
\hline Industry FE & Yes & Yes & Yes & Yes & Yes & Yes \\
\hline
\end{tabular}

Table 11 - Deal composition across countries - VC to GDP - Panel D

\begin{tabular}{|c|c|c|c|c|c|c|}
\hline & $(1)$ & $(2)$ & (3) & $(4)$ & $(5)$ & $(6)$ \\
\hline & \multicolumn{6}{|c|}{ Stage of development } \\
\hline & \multicolumn{2}{|c|}{ Initial idea } & \multicolumn{2}{|c|}{ Marketing and development } & \multicolumn{2}{|c|}{ Revenue generating } \\
\hline $\begin{array}{l}(0,1) \text { Venture received funding from } \\
\text { angel group }\end{array}$ & $-0.096 * * *$ & $-0.114 * * *$ & -0.014 & -0.022 & $0.109 * * *$ & $0.136 * *$ \\
\hline & $(0.025)$ & $(0.038)$ & $(0.036)$ & $(0.054)$ & $(0.036)$ & $(0.054)$ \\
\hline VC to GDP Ratio & $\begin{array}{c}-132.773 * * * \\
(28.746)\end{array}$ & $\begin{array}{c}-137.587 * * * \\
(29.439)\end{array}$ & $\begin{array}{c}4.826 \\
(37.883)\end{array}$ & $\begin{array}{c}2.660 \\
(39.442)\end{array}$ & $\begin{array}{c}127.947 * * * \\
(35.763)\end{array}$ & $\begin{array}{c}134.927 * * * \\
(37.449)\end{array}$ \\
\hline \multirow{2}{*}{$\begin{array}{l}(0,1) \text { Venture received funding from } \\
\text { angel group *VC to GDP Ratio }\end{array}$} & & 25.176 & & 11.329 & & -36.504 \\
\hline & & $(23.350)$ & & $(53.896)$ & & $(53.951)$ \\
\hline Observations & 1,356 & 1,356 & 1,356 & 1,356 & 1,356 & 1,356 \\
\hline R-squared & 0.087 & 0.088 & 0.024 & 0.024 & 0.067 & 0.067 \\
\hline Year FE & Yes & Yes & Yes & Yes & Yes & Yes \\
\hline Industry FE & Yes & Yes & Yes & Yes & Yes & Yes \\
\hline
\end{tabular}

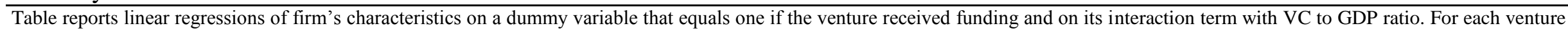

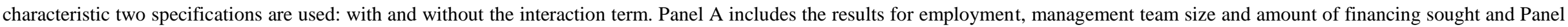

$\mathrm{B}$ adds the results for venture's stage of development. $*, * *$ and $* * *$ denote statistical significance at $10 \%, 5 \%$ and $1 \%$ levels respectively. Robust standard errors are reported. 